\title{
ETTERLATTES ERSTATNINGSRETTSLIGE VERN ETTER VOLDSOFFERERSTATNINGSLOVEN
}

\author{
Kandidatnummer: 667 \\ Leveringsfrist: 25.11.2008
}

Til sammen 17957 ord

18.11 .2008 


\section{Innholdsfortegnelse}

$1 \quad$ INNLEDNING $\quad 1$

$\begin{array}{lll}1.1 & \text { Tema for avhandlingen } & 1\end{array}$

$\begin{array}{llr}1.2 & \text { Problemstilling } & 2\end{array}$

$\begin{array}{lll}1.3 & \text { Avgrensninger } & 3\end{array}$

1.4 Rettskilder 5

1.4.1 Lovtekst, forskrift og forarbeider

1.4.2 Rettspraksis 6

1.4.3 Praksis fra Erstatningsnemnda for voldsofre 6

1.4.4 Praksis ved Kontoret for voldsoffererstatning. $\quad 7$

1.4.5 Reelle hensyn 8

$\begin{array}{lll}1.5 & \text { Videre fremstilling } & 8\end{array}$

$\underline{2}$ BAKGRUNNEN FOR DEN FORMELLE RETTEN

$\begin{array}{lll}2.1 & \text { Fra billighetserstatning til rettskrav } & 10\end{array}$

$\begin{array}{lll}2.2 & \text { Endringer i voldsoffererstatningsloven } & 12\end{array}$

$\begin{array}{lll}2.3 & \text { Etterlattes konvensjonsvern } & 12\end{array}$

$\underline{3}$ DEN FORMELLE RETTEN 14

$\begin{array}{lll}3.1 & \text { Innledning } & 14\end{array}$

$\begin{array}{lll}3.2 & \text { Vilkårene } & 14\end{array}$

$\begin{array}{lll}\text { 3.2.1 Den erstatningsbetingende handling } & 14\end{array}$

3.2.2 Skade/tap og årsakssammenheng $\quad 18$

3.2.3 Det skjerpede beviskravet 19 
3.3 Erstatningsutmålingen $\quad 23$

3.3.1 Innledning 23

3.3.2 Tap av forsørger 24

3.3.3 Utgifter tilknyttet dødsfallet 26

3.3.4 Oppreisning 27

3.3.5 Voldsoffererstatningsordningens beløpsgrenser 34

$3.4 \quad$ Oppsummering og foreløpige betraktninger 36

$4 \quad$ DEN REELLE RETTEN $\quad 39$

$\begin{array}{lll}4.1 & \text { Innledning } & 39\end{array}$

$\begin{array}{lll}4.2 & \text { Metode } & 39\end{array}$

4.3 Vilkårene $\quad 42$

4.3.1 Innledning $\quad 42$

4.3.2 Den straffbare handlingen 43

4.3.3 Årsakssammenheng og beviskrav $\quad 46$

$\begin{array}{lll}\text { 4.3.4 Sammenfatning } & 49\end{array}$

$\begin{array}{lll}4.4 & \text { Hvordan utmåles erstatningen? } & 51\end{array}$

4.4.1 Erstatning for $\varnothing$ konomisk tap $\quad 51$

4.4.2 Hvordan oppreisningen utmåles $\quad 52$

4.4.3 Hvilke virkninger har den $\varnothing v r e$ beløpsgrensen for etterlatte? $\quad 57$

$\begin{array}{lll}\text { 4.4.4 Sammenfatning } & 61\end{array}$

$\underline{5}$ SAMLENDE BETRAKTNINGER $\quad 63$

$\begin{array}{lll}5.1 & \text { Innledning } & 63\end{array}$

5.2 Imøtekommer ordningen lovens formål og etterlattes forventninger til den? $\quad 63$

$\begin{array}{lll}\text { 5.2.1 Ordningens betydning } & 63\end{array}$

$\begin{array}{lll}\text { 5.2.2 Etterlattes rettssikkerhet } & 64\end{array}$

5.2.3 Etterlattes møte med juristene $\quad 65$

5.2.4 Har voldsofre og etterlatte lik mulighet for dekning av tap? 66

$\begin{array}{lll}\text { 5.2.5 Offerrollen } & 68\end{array}$ 
5.3 Rettspolitiske betraktninger $\quad 69$

$\begin{array}{lll}\text { 5.3.1 Lovens begrensninger } & 69\end{array}$

$\begin{array}{lll}\text { 5.3.2 } & \text { Bedre ivaretakelse av etterlattes vern? } & 69\end{array}$

$\begin{array}{lll}5.3 .3 & \text { Oppsummering } & 73\end{array}$

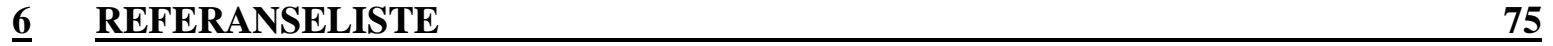

$\underline{7} \quad$ LISTER OVER TABELLER OG FIGURER M V $\quad 85$

8 VEDLEGG 1: ANBEFALELSESBREV $\quad$ A

9 VEDLEGG 2: VEDTAK OM INNSYN $\quad$ B 


\section{$1 \quad$ Innledning}

\subsection{Tema for avhandlingen}

Temaet for avhandlingen er å kartlegge etterlattes ${ }^{1}$ formelle og reelle erstatningsrettslige vern etter voldsoffererstatningsloven. ${ }^{2}$ Voldsoffererstatningsloven ble endret i $2008,{ }^{3}$ og et klart uttrykt formål i forarbeidene til endringsloven ${ }^{4}$ er at etterlatte skal få en styrket stilling. ${ }^{5}$ Dette setter etterlattes stilling i sentrum, og deres erstatningsrettslige vern er derfor et aktuelt tema.

Etterlattes erstatningsrettslige vern har blitt satt på spissen i forbindelse med den $\emptyset$ vre beløpsgrensen i voerstl. $\S 11$. Etter bestemmelsen utbetales det ikke mer enn 20 ganger grunnbeløpet i folketrygden per skadetilfelle, jf. folketrygdloven $\S 1-4 .{ }^{6}$ Et drap regnes etter praksis voldsoffererstatningsloven for ett skadetilfelle. ${ }^{7}$ Der det er flere etterlatte etter avdøde, vil beløpsgrensen kunne virke urimelig. Det utbetales maksimum $20 \mathrm{G}$ uavhengig av antall etterlatte, og av dette tilkjennes de etterlatte erstatning etter sin prosentvise andel av skadevolders samlede erstatningsansvar. ${ }^{8}$

1 Med "etterlatt" forstås den nærmeste personkretsen rundt en person som er død som følge av en straffbar handling som omfattes av voldsoffererstatningsloven.

2 Lov av 20. april $2001 \mathrm{nr} .13$ (voerstl.).

3 Lov av 21. desember 2007 nr. 125. Heretter endringsloven.

4 Kursiveringer i oppgaven er mine egne, så fremt annet ikke fremgår.

5 Jf. Ot.prp. nr. 10 (2007-2008) s. 18.

6 Lov av 28. februar 1997 nr. 19 (ftrl.). Grunnbeløpet (G) utgjør per 1. mai 2008 kr 70 256, jf. http://www.nav.no/page?id=1073744172. Gir et maksimumsbeløp på kr 1405120.

7 Jf. Schønning 1992 s. 123. Ved endringsloven ble dette lovfestet i voerstl. $§ 7$ fjerde ledd.

8 Jf. ENV 2007/4050. 
Det har ikke tidligere blitt foretatt en komparativ analyse om reglene om erstatning til etterlatte etter den norske voldsoffererstatningsordningen, som avhandlingen tar sikte på. Jeg ønsker derfor å gi en oppdatert analyse av de formelle reglene om erstatning til etterlatte, samt belyse sider av den reelle retten. Med formell rett menes retten slik den er i følge rettskildefaktorene (lovtekst, rettspraksis, forarbeider, mv.). Med reell rett siktes det i denne avhandlingen til hvordan den formelle retten rent faktisk blir anvendt ved Kontoret for voldsoffererstatning. ${ }^{9}$

Kartleggingen vil relatere seg til etterlattes vern slik det var før endringsloven trådte i kraft, da Kontoret enda ikke har behandlet noen saker etter dens ikrafttredelse. Praksis etter loven slik den var før 2008 vil likevel ha betydning for saker som skal avgjøres etter endringsloven. Jeg vil derfor foreta en gjennomgang av de nye reglene, og gi en vurdering av om disse vil komme til å bedre etterlattes stilling.

\subsection{Problemstilling}

En kartlegging av etterlattes erstatningsrettslige vern, nødvendiggjør en gjennomgang av hvilke regler som gir etterlatte rett til voldsoffererstatning, samt hvordan disse skal tolkes og anvendes. Jeg vil derfor ta for meg inngangsvilkårene for at etterlatte kan tilkjennes voldsoffererstatning, og reglene for erstatningsutmålingen.

Reglene for utmåling er knyttet opp mot de alminnelige erstatningsrettslige utmålingsreglene. I hovedsak vil behandlingen konsentreres om reglene som avviker fra den alminnelige erstatningsretten. Dette vil for $\varnothing v$ rig lede meg inn på en vurdering av regelen om beløpsgrensen som det ikke opereres med i alminnelig erstatningsrett. Jeg vil undersøke hvilken betydning grensen har for etterlatte som søker om voldsoffererstatning, og vurdere rimeligheten av den.

$9 \quad$ Heretter Kontoret. 
Videre vil kartleggingen bestå av en empirisk analyse av hvordan de formelle reglene faktisk anvendes. Målsettingen er å kartlegge et utsnitt av den reelle retten. Søkelyset rettes mot rettsanvendelsen ved Kontoret, som mottar og behandler søknadene om voldsoffererstatning i første instans. Analysen vil derfor bestå i en gjennomgang av vedtak fattet av Kontoret.

\subsection{Avgrensninger}

I avhandlingen behandles reglene for etterlattes rett til voldsoffererstatning som avviker fra alminnelig erstatningsrett, og det avgrenses mot en generell behandling av de alminnelige reglene i skadeserstatningsloven. ${ }^{10}$

Det avgrenses videre mot behandling av de prosessuelle vilkårene i voldsoffererstatningsloven, da den empiriske analysen avdekket at disse i liten grad begrenser etterlattes rett til voldsoffererstatning. Videre er avhandlingen erstatningsrettslig, slik at strafferettslige problemstillinger kun blir drøftet der dette har betydning for forståelsen av reglene i voldsoffererstatningsloven.

Det er et alminnelig erstatningsrettslig prinsipp at en skade skal erstattes bare én gang. Etter voerstl. § 9 skal det derfor gjøres fradrag i erstatningsutmålingen for blant annet trygde- og forsikringsytelser, som etterlatte er berettiget til som følge av skaden. Bestemmelsen avviker noe fra skl. $§ 3-1$ tredje ledd. ${ }^{11}$ Av hensyn til avhandlingens omfang avgrenses det mot en nærmere behandling av fradragsreglene.

Avhandlingen relaterer seg til norsk rett, og jeg gir kun en kort oversikt over etterlattes konvensjonsrettslige vern. I tilknytning til konvensjonsrettslige regler, vil jeg her påpeke at erstatningsmyndighetene kan ilegge skadevolder erstatningsansvar selv om han er frifunnet

\footnotetext{
10 Lov av 13. juni 1969 nr. 26 (skl.).

11 Se Ot.prp. nr. 4 (2000-2001) s. 45.
} 
i straffesaken. Dette har en side mot Norges konvensjonsrettslige forpliktelser. Etter uskyldspresumsjonen i Den europeiske menneskerettighetskonvensjonen (EMK) ${ }^{12}$ art. 6 nr. 2 og FNs internasjonale konvensjon om sivile og politiske rettigheter (SP) ${ }^{13}$ artikkel 14 (2), er enhver uskyldig inntil det motsatte er bevist. ${ }^{14}$ I dette ligger at enhver rimelig tvil skal komme tiltalte til gode. ${ }^{15}$

Erstatningsansvar til tross for frifinnelse medfører etter rettspraksis ikke en krenkelse av uskyldspresumsjonen. ${ }^{16}$ Begrunnelsen for erstatning må imidlertid ikke reise tvil om frifinnelsen var riktig, ${ }^{17}$ og det må ikke foretas en strafferettslig skyldkonstatering. ${ }^{18}$ Etter forarbeidene foretar ikke voldsoffererstatningsmyndighetene strafferettslig skyldkonstateringer. ${ }^{19}$ Avhandlingen behandler ikke nærmere forholdet mellom frifinnelse og erstatning.

12 Konvensjon av 4. november 1950.

13 Konvensjon av 16. desember 1966.

14 Konvensjonene ble norsk lov ved menneskerettsloven av 21. mai 1999 nr. $20 \S 2$.

15 Jf. Strandbakken 2003 s. 27 og Møse 2002 s. 366.

16 B1.a. Ringvold (Rt. 1996 s. 864, s. 869).

17 Jf. Aall 2003 s. 252. Se også fellende dom mot Norge i Den europeiske menneskerettsdomstol (EMD), Case of Orr v. Norway. Den norske domstolen hadde begrunnet erstatningskravet slik at det skapte tvil om frifinnelsen. Dommen er streng, og kan gjøre det vanskeligere for voldsofre å få erstatning. Dommen skal behandles på nytt i menneskerettsdomstolens storkammer.

18 Jf. Karmøy (Rt. 1999 s. 1363, s. 1378).

19 Jf. Ot.prp. nr. 4 (2000-2001) s. 22. 


\subsection{Rettskilder}

\subsubsection{Lovtekst, forskrift og forarbeider}

Erstatning fra staten til voldsofre er hjemlet i voldsoffererstatningsloven og voldsoffererstatningsforskriften. ${ }^{20}$ Dersom regelsettene angir ulikt resultat på et rettsspørsmål, skal loven i følge reglene om rang mellom rettsregler i utgangspunktet gå foran forskriften. ${ }^{21}$ Regelsettene er imidlertid likestilte. Hvilket av dem som kommer til anvendelse beror på når den straffbare handlingen er begått.

For å klarlegge hvordan bestemmelsene som gir etterlatte rett til voldsoffererstatning skal tolkes og anvendes, må reglenes innhold fastlegges ved bruk av alminnelig juridisk metode. Ved tolkningen tas det utgangspunkt i en naturlig språklig forståelse av ordlyden i bestemmelsene, og denne suppleres med tolkningen av de øvrige rettskildefaktorene. ${ }^{22}$

Reglene for utmåling av voldsoffererstatning er knyttet opp mot reglene i skadeserstatningsloven, i en form som er tilpasset sammenhengen i voldsoffererstatningsloven. Dette innebærer at hvis voldsoffererstatningsordningen ikke angir særskilte regler, så skal reglene tolkes slik at de harmonerer med alminnelige erstatningsregler.

I tillegg til ordlyden er forarbeidene til voldsoffererstatningsordningen gjennomgående av interesse for å klarlegge reglenes innhold. De viktigste forarbeidene er forarbeidene til forskriften, St.prp. nr. 39 (1975-1976) Om bevilgning under kap. 424 i samband med innføring av en ordning om erstatning fra staten til ofre fra straffbare handlinger, og forarbeidene til loven, Ot.prp. nr. 4 (2000-2001) Om lov om erstatning fra staten for personskade voldt ved straffbar handling m.m. (Voldsoffererstatningsloven).

\footnotetext{
20 Kgl. res. 23. januar 1981 nr. 8983. Heretter forskriften.

21 Jf. Boe 1996 s. 47.

22 Jf. bl.a. Eckhoff og Helgesen 2001 s. 39.
} 
Videre vil lovens formål ha betydning for tolkningen. ${ }^{23}$ Formålsbetraktninger omfatter både hensyn bak voldsoffererstatningsordningen og alminnelig erstatningsrettslige hensyn, som for eksempel gjenopprettelse. ${ }^{24}$

\subsubsection{Rettspraksis}

Det foreligger ingen høyesterettsdommer knyttet til voldsoffererstatningsloven. Om det hadde foreligget en dom som direkte avgjør et tolkningsspørsmål, er det ingen andre rettskildefaktorer som ville hatt større vekt. ${ }^{25}$ Voldsoffererstatningsloven er likevel knyttet opp mot reglene i skadeserstatningsloven, slik at avgjørelser etter skadeserstatningsloven vil være en relevant rettskildefaktor for voldsoffererstatningsmyndighetene. Spesielt gjelder dette ved utmåling av oppreisning til etterlatte, da normene Høyesterett har angitt er veiledende for Kontoret. ${ }^{26}$ Dommene kan også vise hvordan Kontorets utmåling forholder seg til domstolenes utmålingspraksis.

\subsubsection{Praksis fra Erstatningsnemnda for voldsofre}

Erstatningsnemnda for voldsofre ${ }^{27}$ er klageinstans for vedtak fattet av Kontoret. Hvordan Nemnda tolker regelverket vil være retningsgivende for Kontoret, så lenge praksisen ikke

23 Boe 1996 s. 245-246 anser dette som en egen type reelle hensyn. I avhandlingen anses formålsbetraktninger å være et resultat av andre rettskildefaktorer. Se også Eckhoff og Helgesen 2001 s. $24-25$.

24 Hensyn bak ordningen behandles bl.a. under pkt. 2.

25 Jf. Eckhoff og Helgesen 2001 s. 261.

26 Jf. Ot.prp. nr. 4 (2000-2001) s. 29.

27 Heretter Nemnda. 
er underkjent av domstolene. ${ }^{28}$ At forvaltningen følger sin egen praksis, er et utslag av likhetsprinsippet om at alle like tilfeller skal behandles likt. ${ }^{29}$

Et spørsmål er hvilken vekt forvaltningspraksis tillegges $i$ forhold til andre rettskildefaktorer. I Angiografi (Rt. 2006 s. 1217, avsn. 38) la Høyesterett til grunn at avgjørelser fra Pasientskadenemnda kan gi tolkningsbidrag «i den utstrekning de kan tas som uttrykk for, eller ha gitt seg utslag i, en fast og konsistent praksis, jf. Rt. 2005 s. 1757 , avsnitt 45, som gjaldt Trygderettens praksis». ${ }^{30}$ Etter min mening kan resonnementet overføres til praksis fra Nemnda, slik at nemndsavgjørelsene kan gi bidrag til klarleggingen av reglenes innhold. Jo fastere og mer konsistent praksisen er, desto mer vekt kan den tillegges. ${ }^{31}$ I avhandlingen brukes nemndsavgjørelser som eksempler på hvordan reglene anvendes.

\subsubsection{Praksis ved Kontoret for voldsoffererstatning.}

Som en del av kartleggingen av etterlattes vern, analyseres et utsnitt av rettsanvendelsen ved Kontoret. Det redegjøres for metoden jeg har benyttet i avhandlingens del II.

Da Kontoret er underinstansen til Nemnda, vil Kontorets praksis ha mindre vekt enn nemndspraksis. Et moment som underbygger dette er at Kontorets vedtak ikke er publisert, og således mindre tilgjengelig enn nemndspraksisen. ${ }^{32}$

28 Jf. Eckhoff og Helgesen 2001 s. 233 og Andenæs 2002 s. 90.

29 Jf. Frihagen 2003 s. 87.

30 Momentene har også støtte i teorien, jf. Eckhoff og Helgesen 2001 s. 233.

31 Jf. Eckhoff og Helgesen 2001 s. 233.

32 Jf. Eckhoff og Helgesen 2001 s. 225. 
Vedtakene som fattes ved Kontoret er underlagt taushetsplikt. ${ }^{33}$ Den 18. august 2008 fikk jeg innvilget innsyn i vedtakene av Justisdepartementet. ${ }^{34}$ Justisdepartementet satte som vilkår at personene i vedtakene ikke kan identifiseres i avhandlingen. Jeg skrev også under på en taushetserklæring ved Kontoret, i tråd med forvaltningslovens regler om opplysninger som skal brukes i forskningsøyemed, jf. fvl. $§ 13$ e. Vedtakene i avhandlingen er derfor fullstendig anonymisert.

\subsubsection{Reelle hensyn}

Reelle hensyn er en relevant rettskildefaktor ved forståelsen av reglene. Reelle hensyn er godhetsvurderinger både av resultatet i det enkelte tilfellet og rettsregelen. ${ }^{35}$ En type godhetsvurdering er virkningsorienterte vurderinger. Rettsanvenderen tar da stilling til hvilke virkninger det man vurderer antas å få, og legger avgjørende vekt på om disse er gode eller dårlige. ${ }^{36}$ Slike betraktninger kan for eksempel spille inn ved vurdering av om voldsoffererstatningen virker som et sikkerhetsnett for etterlatte.

\subsection{Videre fremstilling}

Avhandlingen deles inn i to hoveddeler. Den første delen er en rettsdogmatisk analyse, hvor målsettingen er å klarlegge gjeldende rett. Det vil først redegjøres for bakgrunnen for den formelle retten, for å få en forståelse av hvilke hensyn som ligger bak reglene. Deretter behandles vilkårene for etterlattes rett til voldsoffererstatning. Til slutt behandles utmålingsreglene, herunder den øvre beløpsgrensen.

33 Jf. voerstl. § 14 første ledd, jf. Lov av 10. februar 1967 nr. 00 (fvl.) $§ 13$.

34 Med bakgrunn i innvilgelsen bestemte Justisdepartementet at saken ikke måtte forelegges Rådet for taushetsplikt og forskning, jf. forskrift av 15. desember 2006 nr. 1456 (forvaltningsforskriften) $\S 9$ annet ledd.

35 Jf. Eckhoff og Helgesen 2001 s. 371.

36 Jf. Eckhoff og Helgesen 2001 s. 385-386. 
Den andre delen består av en empirisk undersøkelse av hvordan den formelle retten rent faktisk anvendes ved Kontoret. Dette vil kunne gi grunnlag for avslutningsvis å si noe om hvordan etterlattes vern blir ivaretatt etter voldsoffererstatningsloven. 


\section{Bakgrunnen for den formelle retten}

\subsection{Fra billighetserstatning til rettskrav}

Voldsforbrytelser har alltid vært et problem for samfunnet, og ikke minst er de en stor belastning for etterlatte. Det klare utgangspunktet er at skadevolder selv er økonomisk ansvarlig for sine handlinger overfor skadelidte eller dens etterlatte. Et erstatningskrav mot skadevolderen kan imidlertid være verdiløst fordi han er ukjent, har dårlig betalingsevne eller betalingsvilje. ${ }^{37}$

Etterlatte blir hjulpet gjennom sosiale trygde- og støtteordninger og forsikringer, men ikke sjelden vil det gjenstå et udekket $\varnothing$ konomisk tap. ${ }^{38}$ Voldsoffererstatning ytes derfor til etterlatte for at tapet skal dekkes, uavhengig om det finnes en skadevolder som kan betale eller ikke. Voldsoffererstatningsordningen representerer således et unntak fra at skadevolderen er $\varnothing$ konomisk ansvarlig.

Den første statlige ordningen med erstatning til voldsofre ble gitt ved kgl. res. 11. mars 1976. ${ }^{39}$ Forskriften ble senere avløst av en ny forskrift gitt ved kgl. res. 23. januar $1981 .^{40}$ Sistnevnte forskrift utgjør i dag ett av regelsettene for voldsoffererstatning, og gjelder for voldsforbrytelser foretatt etter den 1. januar 1975.

Det var Den Norske Advokatforening som tok initiativet til gjennomføringen av erstatningsordningen. Den ble i første omgang innført som en billighetserstatning, da staten ville stå friere med hensyn til i hvilken utstrekning den skulle tilkjenne erstatning. ${ }^{41}$

37 Momentet er også vektlagt i forarbeidene, jf. Ot.prp. nr. 4 (2000-2001) s. 5.

38 Jf. Ot.prp. nr. 4 (2000-2001) s. 5.

39 At det utbetales erstatning fra statskassen til de som uforskyldt har kommet uheldig ut, har røtter langt tilbake, jf. Tømmerås 2002 s. 68 om billighetserstatning.

40 Senere endret ved kgl. res. 6. desember 1985 og kgl. res. 26. november 1993, jf. Ot.prp. nr. 4 (2000-2001) s. 7.

41 Reglene ble gitt i forskrift, da behovet for endringer kunne bli stort, og det er enklere å forandre en 
I 2001 ble voldsoffererstatningsordningen lovfestet, og loven gjelder for straffbare handlinger foretatt etter den 1. juli 2001. Loven er i all hovedsak en videreføring av forskriften fra 1981. Ordningen ble imidlertid gjort til en rettighetsordning. Videre ble utmålingsreglene knyttet nærmere opp mot utmålingsreglene i skadeserstatningsloven, ${ }^{42}$ og beløpsgrensen ble hevet fra $\mathrm{kr} 200000$ til $20 \mathrm{G}^{43}$

Voldsoffererstatningen begrunnes med at skadevolderne i disse sakene ofte har liten betalingsevne. ${ }^{44}$ Erstatningsrettslig står derfor voldsofre i en særlig ugunstig stilling, ${ }^{45}$ og voldsoffererstatningen skal virke som et sikkerhetsnett for dem. I forarbeidene til voldsoffererstatningsloven ble det påpekt at statens ansvar for å hindre voldsforbrytelser står i en særstilling, og det ble bemerket at:

«Der samfunnet i det enkelte tilfellet ikke lykkes i å forhindre slike handlinger, bør fellesskapet dekke det tap som personskaden fører med seg der dekning for tapet ikke kan oppnås på annen måte.» ${ }^{46}$

Dette ansvaret er bakgrunnen for at erstatning skal være et rettskrav. Lovgiver uttrykker dermed viktigheten av at voldsofre og deres etterlatte kommer skadesløse ut etter voldshandlingen. ${ }^{47}$ Om dette er en realitet eller ikke, behandles i avhandlingens del II. Lovfestingen ble videre begrunnet $\mathrm{i}$ at det ville samsvare bedre med internasjonale forpliktelser, da Norge hadde ratifisert Den europeiske konvensjon av 24. november 1983 om erstatning til voldsofre. ${ }^{48}$

forskrift enn en lov, jf. St.prp. nr. 39 (1975-976) s. 14.

42 Jf. Ot.prp. nr. 4 (2000-2001) s. 28-29.

43 Jf. forskriften $\S 6$ og voerstl. § 11 .

44 Jf. St.prp. nr. 39 (1975-1976) s. 11.

45 Jf. St.prp. nr. 39 (1975-1976) s. 11.

46 Ot.prp. nr. 4 (2000-2001) s. 17.

47 Jf. Innst. O. nr. 46 (2000-2001) pkt. 3.2.

48 Jf. Innst. O. nr. 46 (2000-2001) pkt. 3.2. Oversikt over konvensjonen gis i pkt. 3.2.2. 
Ordningen er av subsidiaer karakter. Dette kommer til uttrykk ved at staten kun dekker etterlattes tap der gjerningsmannen er ukjent eller ikke betaler, og når tapet ikke dekkes på andre måter. Andre ytelser som mottas for skaden, fradras derfor i voldsoffererstatningen. ${ }^{49}$

\subsection{Endringer i voldsoffererstatningsloven}

Den 1. januar 2008 trådte endringene i voldsoffererstatningsloven i kraft, og handlinger foretatt etter dette tidspunktet reguleres av endringsloven. Bakgrunnen for endringene var blant annet å styrke etterlattes stilling ytterligere ved en utvidelse av deres rettigheter. ${ }^{50}$ Gruppen av etterlatte ble utvidet, og utmålingsreglene ble knyttet nærmere opp mot reglene i skadeserstatningsloven.

Reglene vil bli drøftet mer inngående i avhandlingens avsluttende del, i vurderingen av om reglene vil komme til å bedre etterlattes erstatningsrettslige vern.

\subsection{Etterlattes konvensjonsvern}

Gjennom ratifikasjon av Den europeiske konvensjon om erstatning til voldsofre, ${ }^{51}$ forpliktet Norge seg til å ha en statlig voldsoffererstatningsordning. ${ }^{52}$ Konvensjonsreglene er i hovedsak de samme som de norske. I forarbeidene til voldsoffererstatningsloven, ble det forutsatt at de norske reglene oppfylte kravene som oppstilles i konvensjonen. ${ }^{53}$

49 Jf. Ot.prp. nr. 4 (2000-2001) s. 17.

50 Jf. Ot.prp. nr. 10 (2007-2008) s. 18.

51 Om konvensjonens bakgrunn, se konvensjonens forklarende rapport del II A pkt. 6 og 8 .

52 Jf. Innst. O. nr. 46 (2000-2001) pkt. 3.1.1.

53 Jf. Ot.prp. nr. 4 (2000-2001) s. 18 med henvisning til St.prp. nr. 44 (1991-1992) s. 2, hvor det ble vektlagt at praktiseringen av forskriften var tilnærmet regelbundet. 
Konvensjonens regler representerer minimumsrettigheter, jf. art. 1. Dette innebærer at de nasjonale reglene kan gå lenger enn konvensjonens. Et eksempel på det er at den norske voldsoffererstatningsordningen omfatter visse uaktsomme handlinger, mens konvensjonsreglene bare rammer forsettlige forbrytelser. ${ }^{54}$

Erstatning skal utbetales så fremt full erstatning ikke fås fra andre kilder, for eksempel fordi gjerningsmannen ikke betaler. ${ }^{55}$ Konvensjonen er derfor subsidicer i likhet med den norske ordningen. Konvensjonens art. 2 gir etterlatte rett til erstatning. Det er opp til hvert enkelt land hvilken personkrets som skal gis rett til erstatning, og etter art. 5 kan det settes et maksimumsbeløp for utbetaling av erstatning slik norsk rett har gjort.

54 Jf. voerstl. § 1 første ledd, forskriften § 1 første ledd, og konvensjonens art. 2. Se også Innst. O. nr. 46 (2000-2001) s. 5.

55 Jf. art. 2 og 3, og merknadene til art. 2 i konvensjonens forklarende rapport del III. 


\section{Den formelle retten}

\subsection{Innledning}

For at etterlatte skal tilkjennes voldsoffererstatning, er det en forutsetning at de alminnelige erstatningsrettslige grunnvilkårene er oppfylt i forhold til drapshandlingen. Grunnvilkårene kan deles inn i tre hovedgrupper. For det første forutsetter erstatningsplikt et ansvarsgrunnlag. For det andre må det ha oppstått en skade/tap. Endelig er det krav til adekvat årsakssammenheng ${ }^{56}$ mellom den skadevoldende handlingen og skaden, og mellom skaden og tapet.

I punkt 3.2 behandles vilkårene for at etterlatte kan tilkjennes voldsoffererstatning. Ansvarsgrunnlaget drøftes under punkt 3.2.1 om den erstatningsbetingende handlingen. Kravet til handlingens skadefølge og årsakssammenheng behandles i punkt 3.2.2, og beviskravet tas opp i punkt 3.2.3. Utmålingsreglene for $ø$ konomisk og ikke- $\varnothing$ konomisk tap blir behandlet i punkt 3.3 .

Vilkårene er vesentlig de samme etter forskriften, og bestemmelser i forskriften blir bare behandlet der de avviker fra voldsoffererstatningsloven.

\subsection{Vilkårene}

\subsubsection{Den erstatningsbetingende handling}

Etter voerstl. § 1 første ledd må den erstatningsbetingende handlingen være straffbar. Dette forutsetter at handlingen er forbudt ved lov under trussel om straff, og at straffbarhetsbetingelsene i strafferetten er oppfylt. ${ }^{57}$ Straffbarhetsbetingelsene kan

56 Se bl.a. Kjelland 2007a s. 18-19 om årsakssammenheng og begrepene kausualitetsminimalisme og kausualitetsmaksimalisme.

57 Jf. Ot.prp. nr. 4 (2000-2001) s. 25 med henvisning til Schønning 1992 s. 25. 
sammenfattes i fire punkter. Det må finnes et straffebud som passer på handlingen, gjerningsmannen må ha utvist subjektiv skyld, gjerningsmannen må ha vært tilregnelig, og det må ikke foreligge straffrihetsgrunner. ${ }^{58}$

De to sistnevnte straffbarhetsbetingelsene gjøres det unntak fra i voerstl. $\S 1$ første ledd andre punkt. Dette innebærer at voldsoffererstatning kan tilkjennes, selv om handlingen er straffri etter straffeloven. ${ }^{59}$ Unntakene kan begrunnes ut $i$ fra hensynene for å ilegge henholdsvis straffeansvar og erstatningsansvar. Straff er et «onde som staten tilføyer lovovertrederen på grunn av lovovertredelsen, i den hensikt at han skal føle det som et onde». ${ }^{60}$ Formålet med voldsoffererstatning er å dekke voldsofres tap, ${ }^{61}$ og hensynene i erstatningsretten om risikoplassering og gjenoppretting gjør seg gjeldende. Var gjerningsmannen utilregnelig, har han ikke utvist tilstrekkelig skyld til å straffes. Dette hensynet spiller ikke den samme rollen ved spørsmålet om hvem som står nærmest til å bære tapet, og erstatningsansvar kan derfor ilegges.

Selv om det er gjort unntak fra straffbarhetsbetingelser, må handlingen være «en forsettlig legemskrenking eller en annen straffbar handling som har preg av vold eller tvang», jf. voerstl. $\S 1$ første ledd. Grunnen til det er at voldsofre og deres etterlatte stilles i en prioritert stilling fremfor andre skadelidte, da staten kan bli erstatningsansvarlig om den ikke forhindrer voldsforbrytelser. Også hensynet til gode rettsregler tilsier at det stilles krav til handlingen. Om alle straffbare handlinger skulle omfattes, ville kretsen av skadelidte bli veldig stor, og det ville være å dra statens ansvar for langt.

Alternativet «forsettlig legemskrenking» vil som regel gå under alternativet om «annen straffbar handling». Det har selvstendig betydning ved forsettlige integritetskrenkelser som

58 Jf. Andenæs 2005 s. 101.

59 Lov av 22. mai 1902 nr. 10 (strl.).

60 Andenæs 2005 s. 101.

61 Jf. Ot.prp. nr. 4 (2000-2001) s. 16. 
ikke er egentlige voldshandlinger, for eksempel forgiftning. ${ }^{62}$ Er det begått et forsettlig drap, er kravene til handlingen oppfylt.

Spørsmålet videre blir hvilke drapshandlinger som bærer preg av vold eller tvang. Av forarbeidene fremkommer det at med vold menes maktutøvelse mot person, ${ }^{63}$ og i tvang ligger at man ved makt eller trussel om maktanvendelse får en person til å tåle eller unnlate noe. ${ }^{64}$ Begrepene forstås dermed på samme måte som i strafferetten. Alternativet omfatter også uaktsomme drap, ${ }^{65}$ da disse kan ha preg av vold. ${ }^{66}$

Etter voerstl. $\S 1$ tredje ledd, tilkjennes det ikke voldsoffererstatning for skader som omfattes av bilansvarsloven. ${ }^{67}$ Uaktsomme drap med bil etter strl. $§ 239$ faller derfor som hovedregel utenfor ordningen. Begrunnelsen for det er at personer som utsettes for slike skader normalt får bedre dekning etter bilansvarsloven. ${ }^{68}$ Bilansvarsloven dekker imidlertid ikke oppreisning, jf. bal. $\S 6$ andre ledd, ${ }^{69}$ og etterlatte tilkjennes verken oppreisning etter voldsoffererstatningsloven eller bilansvarsloven. Etter voldsoffererstatningsloven gjøres det derfor unntak hvis bilen er brukt som et særlig farlig redskap, i stedet for for eksempel en kniv. $^{70}$

Nemnda anvendte unntaket hvor en skadevolder hadde kjørt inn $\mathrm{i}$ en annen bil, slik at denne kjørte av veien og en av passasjerene døde. I følge retten lå handlingen tett opptil det

62 Jf. Ot.prp. nr. 4 (2000-2001) s. 7.

63 I Sundre (Rt. 1922 s. 73) er voldsbegrepet forstått som «en hvilken som helst kraftanvendelse stor eller liten mot en person for å overvinne en hindring eller en motstand eller å tvinge.»

64 Jf. Ot.prp. nr. 4 (2000-2001) s. 7.

65 Jf. Ot.prp. nr. 4 (2000-2001) s. 7.

66 Jf. Schønning 1992 s. 24.

67 Lov av 3.februar 1961 (bal.)

68 Jf. Schønning 1992 s. 65.

69 Begrunnet $\mathrm{i}$ at oppreisning er et personlig ansvar, jf. «Den som» i skl. § 3-5. At oppreisning har en pønal karakter underbygger dette, se bl.a. Nyggard 2005 s. 165-166.

70 Jf. Schønning 1992 s. 66. 
forsettlige, og Nemnda fant at bilen ble brukt som et «forsettlig redskap for en voldshandling». ${ }^{71}$

Det kan se ut til at det kreves en del før unntaket kommer til anvendelse. ${ }^{72}$ I juni 2008 kom EFTA-domstolen med en rådgivende uttalelse i Nguyen v. Norge (E-8/07). Den fastslår at norsk rett strider mot EØS-direktivene, da oppreisning ikke omfattes av bilansvarsloven. Konsekvensen av dette antas å være at staten påtar seg ansvaret for oppreisning der skadevolder ikke betaler. ${ }^{73}$ Det har enda ikke kommet noen proposisjon om å endre bal. $§ 6$ andre ledd. ${ }^{74}$

Om gjerningsmannen blir dømt i retten, kan voldsoffererstatningsmyndighetene legge til grunn at det er begått en straffbar handling. ${ }^{75}$ En dom er et bevis på dette. Etterlatte kan også tilkjennes voldsoffererstatning selv om straffesaken for eksempel er henlagt. Dette har sammenheng med straffedommers positive rettskraft, ved at en straffedom ikke er bindende for en senere sivil sak. ${ }^{76}$ Videre er beviskravet, som i den alminnelige erstatningsretten, ikke så strengt som i strafferetten. ${ }^{77}$ Voldsoffererstatningsmyndighetene må i slike tilfeller foreta en selvstendig bevisvurdering av om det er begått en straffbar handling. ${ }^{78}$

\footnotetext{
71 ENV 2005/1084a.

72 Undersøkelsen tar sikte på å kartlegge unntaket nærmere.

73 Opplysning fra advokat Jan Gunnar Ness.

74 Vurdert i Ot.prp. nr. 30 (2006-2007) s. 25. Det var ikke ønskelig med en endring før en fikk kjennelsen i Nguyen v. Norge.

75 Jf. Schønning 1992 s. 26.

76 Jf. Hov 2007 s. 480.

77 Beviskravet behandles under pkt. 3.4.

78 Jf. Ot.prp. nr. 4 (2000-2001) s. 7.
} 


\subsubsection{Skade/tap og årsakssammenheng}

Den som har lidd en personskade ${ }^{79}$ som følge av en straffbar handling, eller dennes etterlatte, har rett til voldsoffererstatning, jf. voerstl. $\S 1$ første ledd. ${ }^{80}$ Medfører personskaden $d \phi d e n$, oppstår spørsmålet om etterlatte har krav på erstatning for blant annet tap av forsørger. ${ }^{81}$ Det stilles med andre ord ikke krav til at etterlatte selv må ha blitt påført skade.

Voerstl. § 1 oppstiller krav til årsakssammenheng ved at døden må ha inntrådt «som følge $\mathrm{av}^{82}$ den straffbare handlingen. Dette må vurderes konkret i hvert enkelt tilfelle. Utgangspunktet for vurderingen er betingelseslæren, ${ }^{83}$ hvoretter den skadevoldende

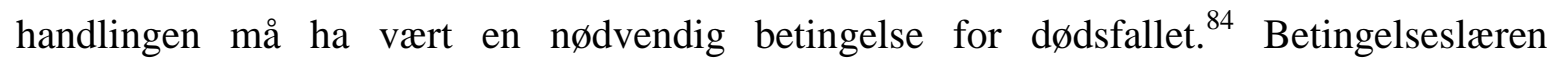
modifiseres av en «uvesentlighetsbegrensning» oppstilt i P-pille II (Rt. 1992 s. 64). ${ }^{85}$ I dette ligger at betingelsen er nødvendig når den har vært så vesentlig i årsaksbildet at det er naturlig å knytte ansvar til den. ${ }^{86}$ Det gjøres derfor «unntak der ansvarshendelsen har ytet et minimalt bidrag til skaden», ${ }^{87}$ og på den måten sjaltes «uvesentlige» årsaker ut.

79 Omfatter fysiske og psykiske skader, jf. Lødrup 2005 s. 33.

80 Skade og tap brukes om hverandre i teorien, men jeg finner det fordelaktig å bruke «skade» i betydningen realskade. Realskaden vil si selve personskaden/krenkelsen.

81 Jf. Lødrup 2005 s. 33.

82 Jf. «voldt» i forskriften $\S 1$.

83 Fastslått i P-pille II (Rt. 1992 s. 64) og stadfestet i Schizofreni (Rt. 2007 s. 172). Den har også støtte i teorien, jf. Nygaard 2007 s. 323 flg. og Lødrup 2005 s. 254 flg.

84 I dette ligger at døden ikke ville inntrådt om handlingen tenkes borte, og det er derfor det knyttes ansvar til handlingen, se P-pille II (Rt. 1992 s. 64, s. 69).

85 Se Kjelland 2007b s. 57 flg., Nygaard 2007 s. 331 og 355 og Lødrup 2005 s. 262-264.

86 Senere fulgt opp i bl.a. Rossnes (Rt. 1997 s. 1) og Nilsen (Rt. 2001 s. 320).

87 Kjelland 2007b s. 57. 
Kravet til årsakssammenheng kommer til uttrykk på følgende måte i et vedtak fra Nemnda:

\begin{abstract}
«Alminnelige erstatningsrettslige prinsipper får anvendelse også i saker om voldsoffererstatning. Dette innebærer blant annet at det må være årsakssammenheng mellom den skadevoldende handling og skaden. Det kreves her klar sannsynlighetsovervekt.
\end{abstract}

For at voldshandlingene skal kunne være en årsaksfaktor må de ha vært en nфdvendig betingelse for at døden inntraff.» ${ }^{88}$

Erstatningsansvaret begrenses videre av adekvansbetraktninger. Skadevolderen skal ikke pålegges ansvar for upåregnelige følger av handlingen. ${ }^{89}$ Begrunnelsen for dette er hensynet til skadevolderen, herunder alminnelige risikofordelingsbetraktninger om hvem som står nærmest til å bære tapet. ${ }^{90}$ I en nemdsavgjørelse bemerkes at «[d]ødsfallet anses videre for å være en påregnelig følge av de straffbare handlinger». ${ }^{91}$

Det kreves videre adekvat årsakssammenheng mellom dødsfallet og etterlattes tap. Ved for eksempel erstatning for tap av forsørger, er kravet oppfylt hvis etterlatte lider tap som følge av at forsørgeren deres er død. Det avgrenses i det følgende mot en nærmere behandling av kravet til årsakssammenheng.

\title{
3.2.3 Det skjerpede beviskravet
}

Etter voerstl. § 3 fjerde ledd kreves det klar sannsynlighetsovervekt for at skadelidte ble drept som følge av en straffbar handling. Etter alminnelig erstatningsrett er hovedregelen

ENV 2005/569.

89 Jf. bl.a. Nilsen (Rt. 2001 s. 320) og Schizofreni (Rt. 2007 s. 172). Se også Lødrup 2005 s. 283.

90 Jf. Lødrup 2005 s. 281 og 293.

91 Jf. ENV 2005/557. 
om beviskrav simpel sannsynlighetsovervekt. ${ }^{92}$ Det vil si at kjensgjerningene som virker mest sannsynlige $(50,01 \%)$ skal legges til grunn.

I legevitenskapen kreves ca. $95 \%$ sannsynlighet. ${ }^{93}$ Dette må man være oppmerksom på ved for eksempel tolkning av rettsmedisinske unders $\emptyset$ kelser. Det debatteres for $\emptyset$ vrig rundt prosentueringen av sannsynligheten. Det hevdes at juristenes prosentuering ikke har grunnlag i vitenskap eller statistikk. Når jurister ber sakkyndige vurdere årsakssammenheng, ber de dem om å prosentuere følelser. ${ }^{94}$ Trolig kan resonnementet overføres til voldsoffererstatningen - for hvordan kommer egentlig voldsoffererstatningsmyndighetene og sakkyndige til at noe er klart sannsynlig?

Voldsoffererstatningsordningen oppstiller således et strengere beviskrav enn alminnelig erstatningsrett. Beviskravet er imidlertid ikke så strengt som for domfellelse, hvor det kreves bevist utover enhver rimelig tvil at tiltalte har begått handlingen. ${ }^{95}$ Beviskravets innhold er grovt antydet i figuren nedenfor.

Figur 1. Visualisering av beviskravets innhold

\begin{tabular}{|c|c|c|c|}
\hline \multirow{2}{*}{\multicolumn{4}{|c|}{ 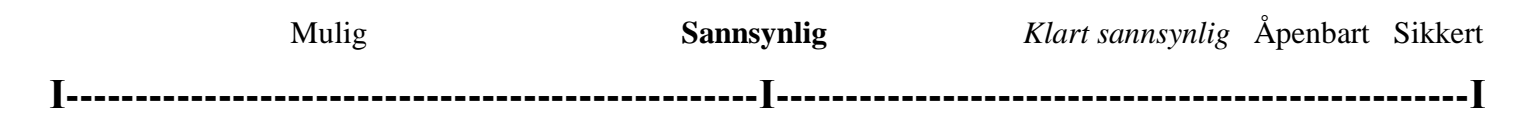 }} \\
\hline & & & \\
\hline $0 \%$ sannsynlighet & $50 \%$ & & $100 \%$ sannsynlighet \\
\hline
\end{tabular}

92 "Overvektsprinsippet” ble klarlagt i P-pille II (Rt. 1992 s. 64).

93 Jf. Kjelland 2007b s. 79.

94 Se Schiøtz, Wergeland og Bratt 2008 s. 75-76.

95 Jf. Ot.prp. nr. 4 (2000-2001) s. 23-24. 
Formelt kom beviskravet med voldsoffererstatningsloven, og praksisen etter forskriften ble kodifisert. ${ }^{96}$ Begrunnelsen for et skjerpet beviskrav er i følge forarbeidene at:

«Voldsoffererstatningsordningen skiller seg imidlertid fra ordinære erstatningssaker ved at det $\mathrm{i}$ utgangspunktet er et vilkår at en straffbar handling har funnet sted. For å kunne legge til grunn at en slik straffbar handling har funnet sted, bør det kreves noe mer enn bare sannsynlighetsovervekt.» ${ }^{97}$

For å underbygge dette, vises det til at Høyesterett krever klar sannsynlighetsovervekt for at det skal legges til grunn at en frifunnet gjerningsmann likevel har begått handlingen og må betale erstatning. ${ }^{98}$ Beviskravet har således vokst fram i rettspraksis, ${ }^{99}$ og er begrunnet i belastningen for skadevolder å bli erstatningspliktig til tross for frifinnelse. ${ }^{100}$ I forarbeidene til voldsoffererstatningsloven begrunnes beviskravet videre i hensynene bak ordningen:

«...det har vært meningen å stille de samme krav til bevis som domstolene stiller i forbindelse tilkjenning av erstatning direkte fra skadevolderen for denne type handlinger. En annen løsning ville lede til at de personer som forfølger sitt krav direkte overfor den prinsipalt ansvarlige, skadevolderen, stilles overfor strengere beviskrav enn de som søker dekning av staten gjennom voldsoffererstatningsordningen. Dette vil bidra til en uønsket kanalisering av erstatningsansvaret bort fra den prinsipalt ansvarlige og over på staten. Dette vil være i strid med intensjonene bak ordningen...» ${ }^{101}$

I Aluminiumsbåt (Rt. 2005 s. 1322, avsnitt 26) fastslo Høyesterett at beviskravet vil variere etter forholdene i saker hvor skadevolder er frifunnet, men likevel erstatningspliktig. Voldsoffererstatningsloven åpner ikke for relativisering. Beviskravet kan derfor sies å ha kommet i utakt med domstolenes beviskrav, men beviskravet ble ikke endret ved endringsloven.

96 Beviskravet gjelder også etter forskriften, jf. voerstl. § 19.

97 Ot.prp. nr. 4 (2000-2001) s. 23.

98 Jf. Ot.prp. nr. 4 (2000-2001) s. 23 med henvisning til bl.a. Ringvold (Rt. 1996 s. 864).

99 Se NOU 2000: 33 for grundig drøftelse av kravets innhold.

100 Jf. Ot.prp. nr. 4 (2000-2001) s. 24.

101 Ot.prp. nr. 4 (2000-2001) s. 24-25. 
Det er stilt spørsmål om hensynet til skadevolder bør veie tyngre enn hensynet til skadelidte. Senest har det blitt fremmet forslag om lemping av beviskravet i voldtektssaker i NOU 2008:4 Fra ord til handling. ${ }^{102}$ Sannsynligvis vil lemping av beviskravet få større betydning i voldtektssaker enn i drapssaker. Det kan være lettere å bevise et drap enn en voldtekt, da det som regel foretas rettsmedisinske undersøkelser av et lik, mens en voldtekt ofte blir anmeldt etter en tid og bevisene kan være forspilt. Beviskravets betydning i drapssaker undersøkes i avhandlingens del II.

102 Forslaget er under behandling. 


\subsection{Erstatningsutmålingen}

\subsubsection{Innledning}

I alminnelig erstatningsrett kan det ved personskade gis erstatning for økonomisk og ikke$\varnothing$ konomisk tap. Etterlattes $\varnothing$ konomiske tap er i utgangspunktet tap de er pådratt ved å ha mistet sin forsørger, samt utgifter i forbindelse med dødsfallet, jf. skl. § 3-4. Ikke$\varnothing$ konomiske tap tilkjennes i form av oppreisning, jf. skl. § 3-5. ${ }^{103}$

Utmålingsreglene i voldsoffererstatningsloven er knyttet opp mot reglene i skl. kap. 3 . Voldsoffererstatningen begrenses imidlertid av beløpsgrenser etter voerstl. § 11, og det skal etter praksis ikke foretas lemping som angitt i skl. § 1-1, § 1-3 og § 5-2. Videre har ikke domstolenes avgjørelser i konkrete saker rettskraftsvirkninger i forhold til voldsoffererstatningsmyndighetene. ${ }^{104}$ Grunnen til det er at domstolene tar stilling til hva skadevolderen skal betale, mens voldsoffererstatningsmyndighetene bestemmer hvilken erstatning staten skal utbetale. ${ }^{105}$ Praksis etter skadeserstatningsloven vil likevel ha betydning for voldsoffererstatningsmyndighetenes vurderinger.

Etter voerstl. $\quad \S \quad 1$ første ledd har den strafferettslig fornærmede krav på voldsoffererstatning. Bestemmelsen har blitt tolket slik at personer lenger ut i årsaksrekken enn den direkte skadelidte, kun får erstatning dersom de omfattes av $§ 7 .^{106}$

Voerstl. § 7 svarer til skl. § 3-4 og § 3-5 andre ledd, og angir nærmere hva etterlatte kan få dekket. Bestemmelsen har blitt oppfattet som uttømmende. ${ }^{107}$ Dette innebærer at for eksempel etterlatte foreldre, ikke har krav på dekning av inntektstap, selv om dette er tilkjent dem i straffesaken.

\footnotetext{
103 Ménerstatning dekkes ikke, da skadelidte selv må ha blitt skadet, jf. skl. § 3-2 og Nygaard 2007 s. 140.

104 Jf. ENV 2004/256 og Ot.prp. nr. 10 (2007-2008) s. 29.

105 Jf. Ot.prp. nr. 10 (2007-2008) s. 29.

106 Jf. Ot.prp. nr. 10 (2007-2008) s. 18.

107 Jf. Ot.prp. nr. 10 (2007-2008) s. 18.
} 
Etter alminnelig erstatningsrett er det ikke helt klart om etterlatte har krav på å få erstattet slikt tap. ${ }^{108}$ Det beror på en konkret vurdering i det enkelte tilfellet, herunder vurdering av om kravet til adekvat årsakssammenheng er oppfylt.

Nedenfor behandles erstatningspostene etterlatte kan kreve erstattet. Enkelthetene i utmålingen av det økonomiske tapet behandles ikke, da de i hovedsak samsvarer med alminnelig erstatningsrett. Videre er forsørgertapet komplekst, og læren behandles derfor i et nøtteskall.

\subsubsection{Tap av forsørger}

Hovedregelen er at skadelidte skal tilkjennes full erstatning for sitt økonomiske tap. For personskader følger dette av skl. § 3-1 første ledd, som er et utslag av alminnelige erstatningsrettslige prinsipper. Det fremgår av Ølberg (Rt. 1993 s. 1524) at kjernen i erstatningsretten er at skadelidte ikke skal komme dårligere ut med skaden enn uten den. Bak prinsippet om full erstatning ligger hensynet til gjenoppretting. ${ }^{109}$ Videre hviler prinsippet på prevensjonshensynet, da reglene for erstatningsplikt skal fremme aktsomhet. ${ }^{110}$ Prinsippet gjelder også etter voldsoffererstatningsordningen. ${ }^{111}$

Prinsippet forutsettes etter forarbeidene til skadeserstatningsloven også å gjelde for tap av forsørger. ${ }^{112}$ Da voldsoffererstatningsloven er knyttet opp mot skadeserstatningsloven, antas det samme å gjelde for tap av forsørger etter voldsoffererstatningsloven. Det er tapet

\footnotetext{
108 Jf. Ot.prp. nr. 10 (2007-2008) s. 18.

109 Jf. Lødrup 2005. s. 79.

110 Jf. Lødrup 2005. s. 86.

111 Jf. Schønning 1992 s. 20 og s. 90

112 Jf. Ot.prp. nr. 4 (1972-1973) s. 5.
} 
av en forsørger, målt i penger, som er gjenstand for erstatning. Dette tapet kan være mindre enn det faktiske tapet etterlatte er pådratt ved dødsfallet. ${ }^{113}$

Etter voerstl. $§ 7$ første ledd, må den etterlatte ha blitt helt eller delvis fors $\phi r g e t$ av avdøde, eller kunne påregne slik forsørgelse i nær framtid. Dette følger også etter forskriften $\S 1$ tredje ledd. Det må derfor klarlegges hva som ligger i fors $\phi$ rgelse.

Etter forskriften $\S 1$ tredje ledd, kreves det ikke et faktisk forsørgerforhold ved dødsfallet, men en lovbestemt plikt til forsørgelse. ${ }^{114}$ Søkeren må likevel påvise et $\emptyset$ konomisk tap som følge av at forsørgeren er død, eller sannsynliggjøre at han ville kunne bli forsørget. ${ }^{115}$ Etter voerstl. $§ 7$, er det avgjørende hvem avdøde faktisk forsørget da han døde. Kretsen av etterlatte som kan få erstatning er dermed snevrere etter forskriften enn etter voldsoffererstatningsloven.

Ved utmålingen er det meningen at etterlatte skal kunne opprettholde sin tilvante levestandard. ${ }^{116}$ Forhold som etter voerstl. $\S 7$ første ledd skal tas i betraktning ved utmålingen, er forsørgingens omfang og den etterlattes muligheter til selvforsørging. I dette ligger en fastsetting av blant annet avdødes inntektsforhold og bidrag til familiens utgifter, og det må tas hensyn til den gjenlevendes egne midler. ${ }^{117}$ Som en del av forsørgertapet er også verdien av forsørgelse i form av arbeid og omsorg i hjemmet. ${ }^{118}$

\footnotetext{
113 Jf. bl.a. Svanevik (Rt. 1976 s. 1302).

114 Jf. Schønning 1992 s. 53, med henvisning til bl.a. lov av 8. april 1981 nr. 7 (bl.). 30 som sier at foreldre «er skyldige til å gje barnet forsvarleg oppseding og forsyting».

115 Jf. Schønning 1992 s. 53.

116 Jf. Bastrup (Rt. 1998 s. 639, s. 643).

117 Se Lødrup 2008 s. 118 flg. om tap av forsørger.

118 Jf. Bastrup (Rt. 1998 s. 639, s. 647) og det såkalte Bastrup-tillegget.
} 


\subsubsection{Utgifter tilknyttet dødsfallet}

Etterlatte skal få dekket utgifter de har i forbindelse med gravferden, jf. voerstl. $\S 7$ andre ledd. ${ }^{119}$ Dette er $\varnothing$ konomisk tap de er påført som følge av dødsfallet, og således et tap som må dekkes hvis de skal få full erstatning. Utgiftene utgjør ikke et fast beløp, men er de utgifter det er vanlig å påregne ved en gravferd, typisk utgifter til gravstein. ${ }^{120}$ Det er ikke et vilkår at man var forsørget av avdøde for å bli tilkjent begravelsesutgifter etter voerstl. $\S 7 .{ }^{121}$

Hvis det finnes rimelig, kan også andre utgifter i anledning dødsfallet erstattes, jf. voerstl. $\S 7$ andre ledd. Etter kravet til årsakssammenheng må utgiftene være pådratt som følge av dødsfallet. Et eksempel på dette er et vedtak hvor Nemnda bemerker at:

«... Når det gjelder vurdering av hva som er rimelig tar nemnda utgangspunkt i hva som følger av alminnelig erstatningsrett. Avgjørende må her være om utgiftene står i rimelig og naturlig sammenheng med skaden.» 122

Eksempler på utgifter som kan dekkes er reiseutgifter i forbindelse med deltakelse i begravelsen, visse behandlingsutgifter, ${ }^{123}$ reiseutgifter fra utlandet og utgifter til kost og losji i forbindelse med overværing av straffesaken mot skadevolderen. ${ }^{124}$

\footnotetext{
119 Det samme etter forskriften, jf. Schønning 1992 s.52.

120 Mottatt gravferdsbidrag og forsikring fradras etter voerstl. $\S 9$.

121 Det samme etter forskriften, jf. Schønning 1992 s.52. Og etter skl. § 3-4 er det den som har rimelig grunn til å påta seg utgiftene, får dem dekket, jf. Nygaard 2007 s. 155-156.

122 Jf. ENV 2005/230.

123 Jf. ENV 2000/284.

124 Jf. ENV 2004/2290.
} 


\subsubsection{Oppreisning}

\subsubsection{Innledning}

Oppreisning er erstatning for ikke-økonomisk tap og skal erstatte tort og svie. Oppreisning har hatt både en preventiv og pønal funksjon, ved at den skal virke som en straff for skadevolder. ${ }^{125}$ I senere tid er formålet med oppreisningen flyttet mer mot det å gi kompensasjon for krenkelsen man har vært utsatt for. ${ }^{126}$ Oppreisningen skal således ha en "plaster på såret"- funksjon. ${ }^{127}$

\subsubsection{Vilkår}

Den som forsettlig eller grovt aktløst har voldt en annens død, kan pålegges å betale oppreisning med en engangssum som retten finner rimelig, jf. skl. § 3-5 andre ledd, jf. første ledd. Skadevolderen er personlig ansvarlig. Ansvaret kan derfor ikke dekkes av arbeidsgiveransvar eller ansvarsforsikring. ${ }^{128}$

Etter voerstl. $\S 7$ tredje ledd kan det ytes oppreisning etter reglene i $\S 6$ til avdødes ektefelle, samboer, barn eller foreldre. Bestemmelsen i $\S 6$ svarer til skl. § 3-5. Personkretsen som kan kreve oppreisning er den samme etter begge regelsettene, og søsken faller utenfor begge ordningene.

Etter forskriften $\S 6$ fjerde ledd erstattes ikke- økonomisk tap hvis særlige grunner foreligger. Tap av nære pårørende er ansett som særlig grunn hvis betingelsene ellers foreligger. ${ }^{129}$

Skl. § 3-5 krever at den skadevoldende handlingen er voldt «forsettlig eller grovt aktløst». Ses voerstl. § 6 i sammenheng med § 1, oppstilles det også her krav til handlingen og

\footnotetext{
125 Jf. Drapsfors $\phi k$ (Rt. 2005 s. 104, avsn. 34).

126 Jf. Lekestativ (Rt. 2006 s. 61, avsn. 17).

127 Jf. Nygaard 2007 s. 165.

128 Fastslått i Norsk Hovedjernbane (Rt. 1913 s. 619, s. 619).

129 Jf. Schønning 1992 s. 140 og s. 159.
} 
skadevolders skyld. Drapet må ha vært begått med forsett, eller ha preg av vold eller tvang. $^{130}$

Etter alminnelig erstatningsrett må skylden knytte seg til den skadevoldende handlingen. I Akbari (Rt. 1999 s. 887, s. 895) ble det fastslått at skadefølgene ikke må omfattes av forsettet. $^{131} \mathrm{Da}$ utmålingsreglene $\mathrm{i}$ voldsoffererstatningsloven er knyttet opp mot skadeserstatningslovens, ${ }^{132}$ antas dette å gjelde også etter voldsoffererstatningsloven.

Etter skl. § 3-5 «kan» oppreisning tilkjennes. Etter rettspraksis forstås imidlertid bestemmelsen som en «skal»- regel når vilkårene er oppfylt. ${ }^{133}$ Det ligger en forutsetning om dette i Høyesteretts normering av erstatningsnivået ${ }^{134}$ som behandles nærmere nedenfor. Voldsoffererstatningsmyndighetene står også fritt i forhold til om oppreisning skal tilkjennes eller ikke, jf. «kan» i voerstl. $\S 6$ og $\S 7$ tredje ledd. Da bestemmelsene svarer til skl. § 3-5, kan en trekke den slutningen at de skal praktiseres som en «skal»regel. Om dette er tilfelle kan den empiriske unders $\varnothing$ kelsen belyse.

\subsubsection{Utmålingen}

Domstolenes avgjørelser i konkrete saker har ikke rettskraftsvirkninger for voldsoffererstatningsmyndighetene. ${ }^{135}$ Ved oppreisning oppstår spørsmålet hvordan voldsoffererstatningsmyndighetene skal forholde seg til domstolenes oppreisningsnivå.

Regelen om utmåling av oppreisning er skjønnsmessig, da rettesnoren er et rimelighetskriterium. Høyesterett har likevel angitt normer for fastsettelse av

\footnotetext{
130 Samme etter forskriften $\S 6$ første ledd sammenholdt med $\S 1$.

131 Kravet til adekvat årsakssammenheng kan sette grenser for skadefølgene, se pkt. 3.2.2.

132 Jf. Ot.prp. nr. 4 (2000-2001) s. 29.

133 Jf. Drapsfors $\phi k$ (Rt. 2005 s. 104, avsn. 52).

134 Jf. Drapsfors $\phi k$ (Rt. 2005 s. 104, avsn. 52) og Nygaard 2007 s. 166.

135 Se pkt. 3.3.1.
} 
oppreisning. ${ }^{136}$ Normeringstanken bygger blant annet på at utmålingen bør være enkel, da oppreisningskrav ofte blir tatt med i straffesaken etter reglene om borgerlige rettskrav. ${ }^{137} \mathrm{I}$ forhold til oppreisningsutmålingen fremkommer følgende av forarbeidene til voldsoffererstatningsloven:

«Komiteen er enig i at nivået for oppreisning bør ligge på omtrent det samme nivået både etter ordningen med voldsoffererstatning og etter ordinære erstatninger fastsatt av domstolen.» ${ }^{138}$

I dette ligger at normeringen er veiledende for voldsoffererstatningsmyndighetene. Dette kan begrunnes med at hvis nivået er høyere i voldsoffererstatningsordningen enn i domstolene, så får man en uønsket kanalisering av erstatningsansvaret. ${ }^{139}$ Staten vil i større grad bli ansvarlig, og dette strider mot ordningens subsidiaritetsprinsipp. Videre kan det begrunnes i at voldsoffererstatningsmyndighetene skal følge en ensartet praksis, slik at like tilfeller behandles likt.

At domstolenes utmåling er veiledende for voldsoffererstatningsmyndighetene, er også forutsatt i nemndspraksis. ${ }^{140}$ Utmålingen kan likevel fravikes dersom voldsoffererstatningsmyndighetene for eksempel finner at beløpet strider mot lovgivers oppfatning. ${ }^{141}$

\footnotetext{
136 Jf. bl.a. Lødrup 2005 s. 380.

137 Jf. bl.a. Knivdrap (Rt. 2001 s. 274, s. 278) og Nygaard 2007 s. 169.

138 Innst. O. nr. 46 (2000-001) pkt. 3.2.

139 Jf. Ot.prp. nr. 4 (2000-2001) s. 29.

140 Jf. bl.a. ENV 2004/332 og ENV 2004/2113.

141 Jf. Ot.prp. nr. 4 (2000-2001) s. 29, hvor det også fremheves at om slik forvaltningspraksis blir kjent, så kan den påvirke rettspraksis.
} 


\subsubsection{Oppreisningsnivå og normering}

I rettspraksis har det utkrystallisert seg et nivå for oppreisningen i drapssaker. ${ }^{142}$ Ut i fra rimelighetskriteriet skal utmålingen likevel baseres på individuelle vurderinger, og fastsettes skjønnsmessig. Ved død er skaden definert ved avdødes relasjon til de etterlatte. Det er deres tap og sorg på grunn av dødsfallet, og måten dette skjedde på, som utgjør skaden. ${ }^{143}$

Oppreisningsbeløpet blir vurdert i forhold til de konkrete forholdene i saken. Det vil være forskjell på overlagt drap og uaktsomt drap på grunn av ulikheter i skyldgraden. Videre vil etterlattes situasjon være sentral i vurderingen, og det skal utmåles et beløp til hver enkelt etterlatt. $^{144}$

Utmåling av oppreisning for forsettlig drap var ikke prøvd i Høyesterett før i Knivdrap (Rt. 2001 s. 274, s. 279). Saken gjaldt oppreisning til moren til en 16 år gammel gutt som var blitt knivstukket og drept i hjemmet deres. Førstvoterende kom til at oppreisning til etterlatte står i en annen stilling enn for andre voldsofre, da etterlatte lider et uopprettelig tap, og bemerket at:

«Ved den skjønnsmessige utmåling av oppreisning til de etterlatte i forbindelse med straffedom for forsettlig drap vil det være vanskelig å gradere oppreisningsbeløpet ut fra handlingens objektive grovhet og skadevolderens skyld. Etterlattes subjektive opplevelse av krenkelsen og arten og omfanget av de påførte psykiske skadevirkninger gir heller ikke noe godt grunnlag for differensiering. Den subjektive opplevelse og ettervirkningene avhenger av personlige forutsetninger.

Disse forhold taler for at oppreisning til foreldre som mister sine barn og eventuelt andre grupper av etterlatte bør normeres. Dette innebærer ikke at normen blir den samme for alle grupper.» (s. 278)

\footnotetext{
142 Jf. bl.a. Hagelgevar (Rt. 2004 s. 1324, avsn. 36).

143 Jf. Nygaard 2007 s. 170.

144 Jf. Lødrup 2005 s. 380.
} 
Etter en vurdering av praktiske hensyn og sprikende utmålingspraksis i domstolene og voldsoffererstatningsordningen, bemerket førstvoterende følgende om normeringen:

«Normeringen av oppreisning til de etterlatte i saker om forsettlig drap må nødvendigvis bli svært skjønnsmessig. Den normerte oppreisning vil være veiledende, slik at retten kan fastsette et høyere eller et lavere beløp når sarrlige forhold tilsier det.» (s. 278)

Etter en gjennomgang av en varierende underrettspraksis ble normen enstemmig satt til $k r 120000 .^{145}$

Ved at det ble fastsatt en norm i et slikt tilfelle, kan det legges til grunn at Høyesterett anser dette som et «normaltilfelle» av forsettlig drap. Det skal en del til før normen kan fravikes, da det kreves sarlige forhold for det. At saksforholdene er ulike, vil sannsynligvis ikke være tilstrekkelig. På den andre siden er normen veiledende, slik at det skal være rom for individuelle vurderinger.

I Giftdrap (Rt. 2002 s. 481) ble to etterlatte barn tilkjent kr 300000 hver. Deres mor døde etter å ha blitt forgiftet av sin mann. Høyesterett viste til at Knivdrap (Rt. 2001 s. 274) selv bemerker at dommen ikke tar stilling til om oppreisning til mindreårige barn tilsier en mer differensiert utmåling. Høyesterett konkluderer med at alder og tilknytning vil ha betydning der barn mister foreldrene sine, og at den foreliggende saken gjelder

«...to mindreårige jenter som mistet sin mor og ene omsorgsperson. I tillegg kommer at det foreligger ekstraordincere forhold...Denne saken er derfor ikke under noen omstendighet en sak som egner seg for normert oppreisning.» (s. 486)

De ekstraordinære forholdene knyttet seg til at kvinnen ble forgiftet $\mathrm{i}$ åtte måneder, og var sterkt preget av smerte og angst, og at barna så og opplevde dette. Høyesterett mente at oppreisningen burde ligge på det høyeste nivået en kunne tenke seg for barn som har mistet

145 I Catwalk (Rt. 2003 s. 1459) ble en gutt knivstukket og drept på åpen gate, og hver av foreldrene ble tilkjent kr 120000. 
foreldre ved overlagt drap. ${ }^{146}$ Høyesterett gjør det dermed klart at normert oppreisning ikke passer i alle saker, og dommen er således et godt eksempel på at oppreisningen fortsatt skal fastsettes skjønnsmessig.

I Haglegevar (Rt. 2004 s. 1324) var de etterlatte foreldre etter et voksent barn. Saken gjaldt en mann som døde etter å ha blitt skutt i magen. I dommen vises det til at Knivdrap (Rt. 2001 s. 274) lar det stå åpent hvilket oppreisningsnivå det bør være for andre etterlattegrupper enn foreldre etter barn. Avdøde i den foreliggende saken var godt voksen og flyttet ut for lengst, og det bemerkes følgende:

«Alder og tilknytning må også for etterlattegruppen foreldre være relevante momenter ved fastsettelsen, og jeg finner det på denne bakgrunn rimelig å fastsette beløpet til avdødes foreldre til $100000 \mathrm{kr} . »($ avsnitt 39)

Dette tyder på at beløpet kan settes under norm, når de etterlatte er foreldre etter voksne barn, ${ }^{147}$ da alder og tilknytning er særlige grunner som kan begrunne fravikelse av normen. Når barna er voksne foreligger det ikke lenger et omsorgsforhold på samme måte som når barna er små.

Et eksempel fra Nemnda kan belyse hvordan de fastsetter oppreisningsbeløpet. ${ }^{148}$ Ei jente søkte om oppreisning etter at faren hennes ble drept. Nemnda fant at den veiledende normen var for lav når det er barn som er etterlatt, og at Giftdrap (Rt. 2002 s. 481) ikke egnet seg for standardisering. Nemnda fant uten nærmere begrunnelse at kr 200000 var et passende oppreisningsbeløp. Men det viser at Nemnda, i likhet med rettspraksis, tillegger

\footnotetext{
146 Samme beløp ble tilkjent etterlatte barn i Rica II (Rt. 2004 s. 750), da barna ble frarøvet sin omsorgsperson. (Beløpet ble tilkjent i lagmannsretten, men ble ikke anket.)

147 I Geriljasoldat (Rt. 2004 s. 592) ble avdødes mor tilkjent kr 100000 selv om de ikke hadde sett hverandre på 14 år, da de hadde hatt et nært forhold.

148 ENV 2006/1033. I nemndspraksis er små etterlatte barn tilkjent kr 200 000, men beløpet varierer etter forholdene, jf. ENV 2005/248.
} 
alder og tilknytning vekt, og utmåler derfor et beløp midt i mellom de nevnte høyesterettsdommene.

Rettspraksis for oppreisning ved uaktsomme drap er ikke særlig omfattende. ${ }^{149}$ I Lekestativ (Rt. 2006 s. 61) omkom ei jente etter at hun falt ned fra et lekestativ. Foreldrene ble tilkjent $k r 75000$ i oppreisning. Spørsmålet var om oppreisningen burde normeres, herunder hvorvidt hensynene bak normering av forsettlig drap også slår til ved grovt uaktsomt drap, jf. skl. § 3-5 annet ledd. I dommen fremheves formålet med oppreisning, og at Knivdrap (Rt. 2001 s. 274) sier at etterlattes uopprettelige tap setter dem i en særstilling hva gjelder oppreisning. Førstvoterende kom til at hensynene gjør seg gjeldende overfor uaktsomme drap, og bemerker videre at:

«Generelt må det antas at det i betydelig grad $\varnothing$ ker muligheten for etterlattegruppen til å få oppreisning, at deres krav tas med som et borgerlig rettskrav i straffesaken. Dette er i seg selv et tungtveiende moment for normering...

De hensyn som kan tale mot normert erstatning, er at selve den straffbare handling ved uaktsomme drap har stor variasjonsbredde og spenner over så vidt ulike kategorier som trafikkulykker, jaktulykker, arbeidsplassulykker med mer. Men også innenfor forsettet gjelder at det kan være et betydelig spenn...» (avsnitt 18-19)

Da graden av skyld er ulik, kom Høyesterett til at normen burde ligge under nivået for forsettlige drap. Normen ble enstemmig satt til kr 75 000. Det ble bemerket at den kan fravikes, og også settes høyere enn normen for forsettlig drap, hvis særlige grunner foreligger. ${ }^{150}$

Oppreisning for grovt uaktsomt drap med båt ble behandlet i Båtdrap (Rt. 2007 s. 1777), hvor to kamerater lekte i bølgene i hver sin båt. Den ene ble påkjørt av den andre og døde. Saken skilte seg fra Lekestativ (Rt. 2006 s. 61), da avdøde var etablert med samboer som

\footnotetext{
149 Jf. Nygaard 2007 s. 171.

150 Normen følges også av Nemnda, jf. bl.a. ENV 2007/967.
} 
ventet barn. Høyesterett viste til Haglegevar (Rt. 2004 s. 1324), hvor beløpet ble nedjustert fordi avdøde var godt voksen og etablert. Med bakgrunn i dette fant Høyesterett at:

«...[I] tilfelle der barnet er voksent og etablert med egen bolig bør oppreisningen ved uaktsomt drap til foreldre i alminnelighet settes til 60000 kroner.» (avsnitt 39)

I likhet med normen for forsettlig drap settes oppreisningsbeløpet ned når de etterlatte er foreldre etter voksne barn. I denne dommen ser det ut til at oppreisningen til foreldre etter voksne barn generelt skal være kr 60 000, men det må antas at det fortsatt skal tas utgangspunkt i normen på kr 75000 ved uaktsomme drap.

\subsubsection{Voldsoffererstatningsordningens beløpsgrenser}

Voldsoffererstatningsordningen oppstiller begrensninger både oppad og nedad for hvor mye som kan utbetales i voldsoffererstatning. ${ }^{151}$ Etter forskriften $\S 6$ første ledd nr. 2 er den Øvre beløpsgrensen kr 200 000, og den gjelder for drap begått fra og med 1. januar 1994. ${ }^{152}$

I forarbeidene til voldsoffererstatningsloven ble den $\emptyset$ vre beløpsgrensen foreslått opprettholdt, for at staten skulle kunne forutse sine utgifter. ${ }^{153}$ Det ble imidlertid fremmet forslag om å heve den til kr $1000000 .{ }^{154}$ Tidligere hadde de som var blitt påført de mest alvorlige skadene blitt rammet av grensen. Med en heving av grensen ville også disse normalt oppnå full erstatning. ${ }^{155}$ Om hvordan grensen burde settes bemerket Justiskomiteen følgende:

151 Den nedre beløpsgrensen behandles ikke nærmere, da denne er lite problematisk.

152 Grensen er kr 150000 for drap begått $f \phi r$ dette tidspunktet.

153 Jf. Ot.prp. nr. 4 (2000-2001) s. 28.

154 Jf. Ot.prp. nr. 4 (2000-2001) s. 27.

155 Det er etterlattes nettotap som dekkes med inntil maksimalbeløpet, jf. Ot.prp. nr. 4 (2000-2001) s. 27. 
«For å være sikret en naturlig justering av grensen, anbefaler komiteen at den knyttes til grunnbeløpet i folketrygden, og komiteen fremmer forslag til en endring i § 11 der grensen fastsettes til $20 \mathrm{G}$ i stedet for 1 mill. kroner.» ${ }^{156}$

Komiteen understreket at prinsipielt burde alle skadelidte som oppfyller vilkårene for voldsoffererstatning, sikres full erstatning. ${ }^{157}$ Dette samsvarer bedre med prinsippet om full erstatning i alminnelig erstatningsrett, og hensynet til gjenopprettelse. Komiteen ba derfor om at utviklingen skulle følges nøye for å klarlegge om det i hele tatt burde opereres med en grense. ${ }^{158}$

Grensen på $20 \mathrm{G}$ i voerstl. $\S 11$ gjelder for hvert enkelt skadetilfelle. Etter voldsoffererstatningsmyndighetenes praksis regnes et dødsfall som ett skadetilfelle. ${ }^{159}$ Det vil si at det ikke utbetales mer enn $20 \mathrm{G}$ per drap. ${ }^{160}$

Hvor det er flere etterlatte etter avdøde, vil grensen kunne nås oftere. De $20 \mathrm{G}$ må da fordeles på alle etterlatte etter deres forholdsmessige andel av skadevolders totale erstatningsansvar. ${ }^{161}$ Hvis en mor blir drept og etterlater seg flere barn, så vil disse få mindre erstatning enn om de var enebarn. Dette kan innebære at man tilkjennes et langt høyere erstatningsbeløp i retten enn etter voldsoffererstatningsloven, noe som igjen innebærer et brudd med prinsippet om full erstatning.

Et eksempel på dette er vedtak fra Nemnda der tre små barn mistet moren $\sin .{ }^{162}$ Det yngste barnet fikk tilkjent en million kroner mindre i Nemnda enn i retten på grunn av

\footnotetext{
156 Innst. O. nr. 46 (2000-2001) pkt. 3.2.

157 Jf. Innst. O. nr. 46 (2000-2001) pkt. 3.2.

158 Jf. Innst. O. nr. 46 (2000-2001) pkt. 3.2.

159 Jf. bl.a. ENV 2005/3976.

160 Verdien av $20 \mathrm{G}$ på skadetidspunktet er det avgjørende, jf. Brath 2007 note 30.

161 Eksempel på utregning gis i avhandlingens del II.

162 Jf. ENV 2007/4048.
} 
beløpsgrensen. Hvordan grensen rammer etterlatte undersøkes nærmere i avhandlingens del II.

\subsection{Oppsummering og foreløpige betraktninger}

For at etterlatte skal tilkjennes voldsoffererstatning, kreves klar sannsynlighetsovervekt for at avdøde ble drept av en handling som var forsettlig eller bar preg av vold eller tvang, jf. voerstl. § 1, jf. § 3 fjerde ledd. Hva gjelder handlingens straffbarhet og beviskravet, ser det ut til at Kontoret skal legge rettens avgjørelse der den har tatt stilling til saken. Om handlingen har preg av vold eller tvang må imidlertid vurderes konkret, da ikke alle straffbare handlinger omfattes av voldsoffererstatningsloven.

Rettens erstatningsbeløp er også retningsgivende for Kontoret. Høyesterett har angitt en veiledende norm for oppreisningen, og oppreisningsbeløpet kan variere ut i fra blant annet etterlattes alder og tilknytning til avdøde.

Voldsoffererstatningen skal i utgangspunktet sikre etterlatte full erstatning. Det er imidlertid bestemmelser i voldsoffererstatningsloven som kan begrense dette. For det første er det grunn til å tro at 20 G-grensen vil avskjære etterlatte fra å få full dekning, i alle fall der det er flere etterlatte etter avdøde.

Ved begrunnelsen for $20 \mathrm{G}$-grensen fremhever departementet at:

«En annen ordning vil gjøre det vanskelig å forutberegne statens utgifter. Et tak som nevnt vil dessuten kunne forenkle erstatningsutmålingen i de aller mest omfattende og kompliserte sakene.» ${ }^{163}$

163 Ot.prp. nr. 4 (2000-2001) s. 28. 
Problemstillingen blir om hensynet til at staten skal kunne forutse sine utgifter, skal veie tyngre enn hensynet til etterlatte. Det er forståelig at staten har behov for å forutberegne utgiftene. Argumentet om forenkling av utmåling, er også et hensyn som er viktig i forvaltningen. Saksbehandlingen $\mathrm{i}$ forvaltningen er preget av stor saksmengde og det arbeides ofte under tidspress. ${ }^{164}$

På den andre siden er hovedformålet med voldsoffererstatningen å gi voldsofre og deres etterlatte erstatning for deres tap, og på den måten gi dem økonomisk trygghet. Et argument mot en beløpsgrense er at den kan ramme særskilte grupper av voldsofre, herunder etterlatte.

Både rettferdighetshensyn og gjenopprettelseshensyn tilsier at etterlatte bør ha lik mulighet for å få full erstatning som andre voldsofre. Nødvendigheten av økonomisk kompensasjon kan være like stor for dem som for andre. Kompensasjonen kan med en $\emptyset$ vre grense bli tilfeldig, da den blir avhengig av hvor mange etterlatte det er. Dette viser at det i det minste er et behov for en betydelig heving av grensen.

For det andre begrenses etterlattes rett til full erstatning, da de ikke anses som direkte skadelidte og dermed ikke får dekket tap som nevnt i voerstl. § 4. ${ }^{165}$ Det er ikke utenkelig at for eksempel etterlatte foreldre kan lide et $\varnothing$ konomisk tap om de mister et barn. Dette er et tap som burde kunne dekkes. Problemet er ikke omtalt i forarbeidene, og det kan virke som lovgiver ikke har forutsett denne begrensningen.

I Nemnda er det lagt til grunn at søkere i sjeldne tilfelle kan tilkjennes erstatning selv om de ikke er strafferettslig fornærmet. Det vil avhenge av blant annet om handlingen er egnet til å påføre et psykisk traume, samt tilknytningen til avdøde. ${ }^{166}$ Dersom etterlatte skal ha lik

\footnotetext{
164 Jf. Eckhoff og Helgesen 2001 s. 225-227.

165 Se bl.a. ENV 2004/180.

166 Jf. ENV 2004/316. Praksis fra Nemnda viser at unntaket ikke anvendes ofte.
} 
mulighet til dekning av фkonomisk tap som andre voldsofre, er det etter min mening nødvendig at loven åpner for at også etterlatte kan få dekket tap etter voerstl. § 4 .

Om og i hvilken utstrekning begrensningene rammer etterlatte, tar den empiriske undersøkelsen sikte på å besvare. Dette vil igjen kunne gi grunnlag for å vurdere etterlattes vern etter voldsoffererstatningsloven. 


\section{Den reelle retten}

\subsection{Innledning}

I tillegg til en redegjørelse av den formelle retten, ønsker jeg å kartlegge et utsnitt av rettsanvendelsen ved Kontoret ved hjelp av en empirisk unders $\emptyset$ kelse. Det er ved Kontoret søknadene om voldsoffererstatning avgjøres i første instans, og deres rettsanvendelse danner således grunnlag for å finne ut hvordan reglene praktiseres.

En del av emnene som behandles vil korrespondere med emner i den rettsdogmatiske delen. På den måten vil eventuelle ulikheter og likheter mellom den formelle og den reelle retten lettere synliggjøres. Interessante problemstillinger blir å se hvordan voldsoffererstatningsmyndighetene praktiserer vilkårene, hvordan deres erstatningsutmåling forholder seg til domstolenes, samt hvordan beløpsgrensen fungerer overfor etterlatte.

I det følgende vil jeg behandle inngangsvilkårene for voldsoffererstatning i punkt 4.3, og erstatningsutmålingen i punkt 4.4. Saker som har nådd 20 G-grensen blir deretter behandlet i punkt 4.5, og i punkt 4.6 blir funnene sammenfattet. Det jeg har funnet i den empiriske undersøkelsen vil bli vurdert i et større rettslig perspektiv under punkt 5.

\subsection{Metode}

Opplysningene fra Kontorets vedtak er bearbeidet ved hjelp av dels en kvantitativ og dels en kvalitativ analyse. Den kvantitative analysen gir oversikt over en mengde opplysninger. Den gjør det mulig å trekke ut frekvensfordelinger for å kartlegge for eksempel erstatningsnivået. Den kvalitative metoden gir grunnlag for en analyse som går mer i 
dybden, ${ }^{167}$ og kan bidra i kartleggingen av selve utmålingsprosessen. På den måten kan de sterkeste sidene ved begge metodene utnyttes. ${ }^{168}$

I undersøkelsen har jeg gjennomgått vedtak hvor søknad om voldsoffererstatning ble mottatt ved Kontoret i løpet av 2006 og frem til 1. august 2007. Samtlige saker er avsluttet, og utgjør i alt 114 vedtak. $^{169}$ Ved utvelgelsen av vedtak tok jeg utgangspunkt i registreringsskjemaer som benyttes av saksbehandlerne, hvor det var merket av for at den straffbare handlingen var drap (strl. $§ 233$ og $§ 239$ ), og at etterlatte var blitt tilkjent erstatning. Jeg gjennomgikk saksdokumentene i vedtakene, og skrev korte saksreferat.

Det var mange variabler i vedtakene, og det var derfor arbeidsbesparende å foreta analysen ved hjelp av statistikkprogrammet SPSS for Windows. Opplysninger ${ }^{170}$ fra vedtakene om for eksempel erstatningsutmålingen, ble kodet i en kodebok i SPSS. Deretter ble opplysningene fra vedtakene lagt inn i programmet. På den måten fikk jeg oversikt over variablene i vedtakene, og grunnlag for å analysere dem.

Videre behandlet jeg 26 saker for seg selv, som også ble registrert i SPSS. Dette er alle saker vedrørende etterlatte der utmålingen har nådd beløpsgrensen i voerstl. $\S 11$. Dette er saker som nettopp hadde kommet tilbake fra Justisdepartementet, etter deres gjennomgang av dem i forbindelse med lovendringene som trådte i kraft i 2008. Jeg behandlet sakene for seg selv for å kunne gå mer i dybden av 20 G-problematikken og vurdere maksimumsgrensen.

Eventuelle feilkilder kan være at jeg ikke hadde alle registreringsskjemaene for søknader mottatt i det angitte tidspunktet. Uansett tror jeg at de foreliggende vedtakene er

167 Jf. Hellevik 1995 s. 104-106. Se også Martinussen 1991 s 391-392.

168 Jf. Hellevik 1995 s. 65.

169 Det var flere vedtak som omfattet flere etterlatte. Til sammen er det 46 skadevoldere i undersøkelsen, dvs. 46 drap.

170 Opplysningene ble innhentet fra vedtakene, vedlagte dommer og korrespondanse i saken. 
representative for å kartlegge et utsnitt av den reelle retten. Videre kan det ha skjedd feil ved inntasting i SPSS, men for å sikre reliabiliteten ${ }^{171}$ har jeg dobbeltsjekket alle opplysninger.

Da jeg valgte ut vedtak fra 2006 og fremover, er de fleste vedtakene som avgjøres etter forskriften avsluttet. ${ }^{172}$ Vedtakene er derfor i hovedsak avgjort etter voldsoffererstatningsloven.

I tillegg til analysen av vedtakene, hadde jeg forholdsvis sent $\mathrm{i}$ arbeidet, en samtale med advokatfullmektig Marte Bastiansen. Formålet med spørsmålene jeg stilte henne, var å få innspill fra etterlattes standpunkt, blant annet hennes oppfatning av reglene i voldsoffererstatningsloven. ${ }^{173}$ Intervjuet er ikke representativt, da utvalget av etterlatte er for lite. Det kan likevel gi et innblikk av hvordan ordningen oppleves av etterlatte. Opplysningene fra samtalen er bearbeidet kvalitativt.

\footnotetext{
171 Begrepet brukes om nøyaktigheten av målingene, jf. Hellevik 1995 s. 92.

1727 av 114 saker er behandlet etter forskriften.

173 Om slikt uformelt opplegg, se Hellevik 1995 s. 62.
} 


\subsection{Vilkårene}

\subsubsection{Innledning}

For at etterlatte skal tilkjennes voldsoffererstatning, må inngangsvilkårene være oppfylt. I $71 \%$ av vedtakene fikk etterlatte innvilget søknaden sin helt eller delvis, og det innebærer at 33 vedtak er avslått. Tabellen nedenfor gir en oversikt over hvilke avslagsgrunner som forekom hyppigst.

\section{Tabell 1. Oversikt over avslagsgrunner}

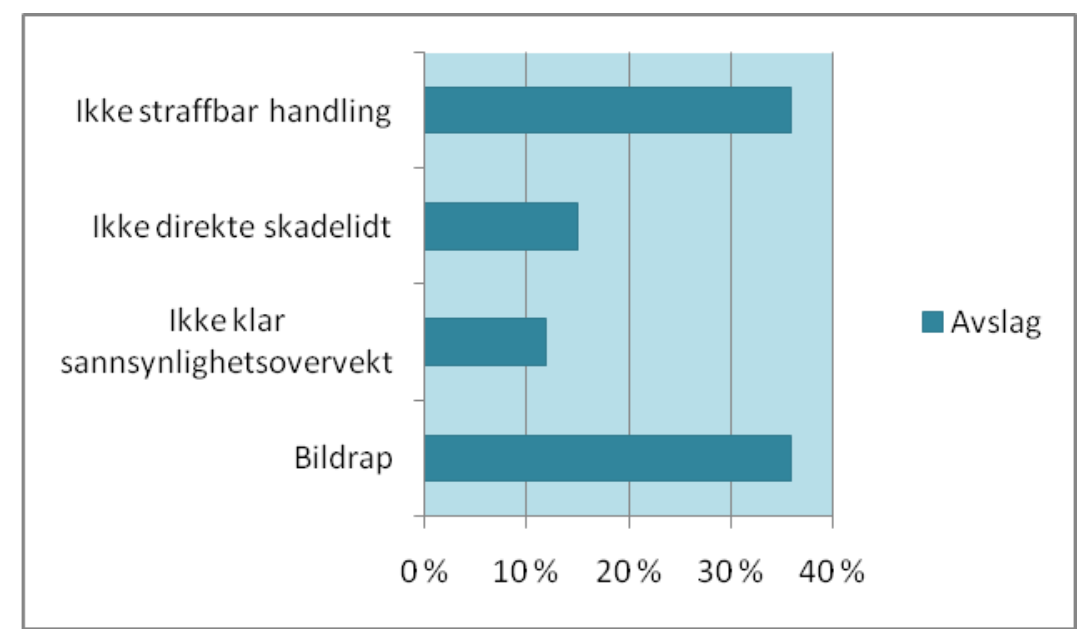

Tabellen viser at en av de mest benyttede avslagsgrunnene, er at handlingen ikke var straffbar i voldsoffererstatningslovens forstand. Videre har mange etterlatte fătt avslag fordi bildrap ikke omfattes av ordningen. Nedenfor presenteres praktiseringen av vilkårene. 


\subsubsection{Den straffbare handlingen}

\subsubsection{Utgangspunktet}

I utgangspunktet skal Kontoret foreta en selvstendig vurdering av handlingens straffbarhet på grunnlag av saksdokumentene, og er derfor ikke bundet av andre instansers vurderinger.

Av undersøkelsen ser det likevel ut til at Kontoret skiller mellom saker hvor gjerningsmannen er domfelt, og saker hvor han ikke er det. Det er reist straffesak mot $89 \%$ av skadevolderne, og de fleste gjerningsmennene er dømt for forsettlig drap. Kontoret legger da ubetinget til grunn at vilkåret er oppfylt. Hvis en sak for eksempel er henlagt, må imidlertid Kontoret selv vurdere handlingens straffbarhet.

Hva gjelder handlinger som har preg av vold eller tvang etter voerstl. § 1, kan det legges til grunn at det er begått en straffbar handling, men det er ikke gitt at handlingen har et slikt preg som loven krever. Etter forarbeidene skal alternativets innhold ha utkrystallisert seg i praksis, og således gi et forholdsvis presist avgrensningskriterium. ${ }^{174}$

Det er $36 \%$ av de avslåtte vedtakene som er avslått fordi handlingen ikke var straffbar i voldsoffererstatningslovens forstand. Nedenfor behandles noen typetilfeller hvor Kontoret har vurdert om handlingen har preg av vold eller tvang.

\subsubsection{Forgiftning}

Vilkåret om handlingens straffbarhet ble ikke ansett for oppfylt, i et tilfelle hvor en kvinne døde etter å ha drukket metanolholdig smuglersprit. Skadevolderne ble dømt for uaktsom forgiftning etter strl. § 153 femte ledd og uaktsomt drap etter strl. § 239 annet straffealternativ.

174 Ot.prp. nr. 4 (2000-2001) s. 7. 
Kontoret la rettens avgjørelse til grunn, og det forelå derfor ikke forsettlig legemskrenking. Spørsmålet ble om handlingen bar preg av vold eller tvang. Det ble vist til hvordan tvang er forstått i teorien, og at voldsbegrepet kan forstås slik det er definert i Sundre (Rt. 1922 s. 73). ${ }^{175}$ Deretter ble det vist til en nemndsavgjørelse, hvor søker hadde drukket etsende plumbo etter at en kollega hadde helt dette i kaffetrakteren. Nemnda kom til at forholdet ikke hadde preg av vold eller tvang. ${ }^{176}$ Kontoret konkluderte derfor med at:

«Disse handlingene bærer ikke preg av vold eller tvang, etter voldsoffererstatningsloven $\S 1$, slik dette begrepet er definert gjennom praksis og juridisk teori.» ${ }^{177}$

Den samme begrunnelsen er gitt i andre liknende saker. I ett tilfelle ble etterlatte tilkjent erstatning på grunn av at avdøde hadde drukket sprit. Da var imidlertid skadevolder dømt for forsettlig forgiftning. Etter dette ser det ut til at uaktsom forgiftning faller utenfor ordningen, fordi forholdet ikke har preg av vold eller tvang.

\subsubsection{Uaktsomme drap}

Det er flere eksempler i undersøkelsen på at etterlatte er tilkjent erstatning for uaktsomme drap etter strl. § 239 som følge av typiske voldshandlinger som slag mot hodet.

Etter voerstl. § 1 tredje ledd omfattes ikke uaktsomme drap med bil, med unntak av tilfeller der bilen er brukt som et særlig farlig redskap. ${ }^{178}$ Et vedtak i undersøkelsen gjaldt oppreisning til foreldrene til en gutt som hadde blitt påkjørt og drept. Kontoret bemerket følgende:

\footnotetext{
175 Jf. pkt. 3.2.1.

176 Jf. ENV 2004/1912.

177 Påklaget til Nemnda som stadfestet vedtaket med samme begrunnelse.

178 Jf. pkt. 3.2.1.
} 
«Etter Erstatningsnemnda for voldsofres praksis tilkjennes det heller ikke erstatning for ikke$\emptyset$ konomisk skade etter voldsoffererstatningsordningen selv om slik erstatning ikke dekkes etter bilansvarsloven, jf. for eksempel sak 2004/01905. Videre vises det til Ot.prp. nr. 4 (2000-2001) side 44 høyre spalte, der det uttales at også forsettlig skadeforvoldelse som faller inn under bilansvarsloven vil falle utenfor voldsoffererstatningsordningen.»

Kontoret fant heller ikke grunnlag for at skadevolder forsettlig brukte bilen som et farlig redskap, da tingretten karakteriserte kjøreatferden som grovt uaktsom og at den ikke tenderte mot forsett.

Av sakene i undersøkelsen er det $36 \%$ av drapene som er bildrap, og samtlige er avslått. Det vil si at Kontoret ikke har anvendt unntaket for farlig redskap i noen saker. De sakene som er påklaget til Nemnda er blitt stadfestet, og dette tyder på at praksisen rundt unntaket er restriktiv.

Et eksempel på det, er hvor en ruspåvirket skadevolder kjørte inn i en fjellvegg og passasjerene døde. På festen før ulykken skal han ha uttalt at «du skal få sjå blodet mitt på fjellveggen», og prøvd å kutte over pulsåren sin. Kontoret la rettens avgjørelse om grov uaktsomhet til grunn. Vedtaket ble påklaget til Nemnda som stadfestet det. ${ }^{179}$ Mindretallet i Nemnda kom imidlertid til motsatt resultat, ved å tillegge vitneuttalelsene og skadevolders uttalelser avgjørende vekt.

I et vedtak nevnt i punkt 3.2.1 kom Nemnda til at bilen ble brukt som et farlig redskap. Slik jeg ser det, var det et tydeligere eksempel på at bilen ble brukt som et redskap enn dette tilfellet. Etter min mening kunne likevel de etterlatte i sistnevnte tilfelle ha blitt tilkjent oppreisning, ved at vitneuttalelsene hadde blitt tillagt mer vekt. ${ }^{180}$

\footnotetext{
179 ENV 2006/712.

180 Se for $\varnothing v$ vig ENV 2007/1159 for mindretallets uttalelse om forholdet til bilansvarsloven.
} 
Etter Nguyen v. Norge ${ }^{181}$ kan staten bli erstatningsansvarlig for ulykker som skjedde en viss tid etter september 2000. ${ }^{182}$ Det antas at Justisdepartementet vil endre bilansvarsloven, ${ }^{183}$ og da vil etterlattes vern etter min mening bli bedre ivaretatt. Frem til da er praksisen den samme etter voldsoffererstatningsloven. ${ }^{184}$

Kontoret kom i et tilfelle til at et uaktsomt drap med båt ikke bar preg av vold. ${ }^{185}$ Vedtaket ble stadfestet av Nemnda, som la vekt på at avdøde deltok i en farlig lek og at sammenstøtet måtte karakteriseres som en ulykke, og ikke en voldshandling. ${ }^{186}$

I en annen sak døde skadelidte etter at en ruspåvirket båtfører kjørte inn i båten hans. Kontoret avslo søknaden, men Nemnda fant at handlingen var en voldshandling, og bemerket at unntaket for bilansvar ikke gjelder tilsvarende for båt. ${ }^{187}$

Det er stor forskjell på saksforholdene i båtdrap-sakene. Selv om sistnevnte tilfelle ikke er en utpreget voldshandling, burde Kontoret kommet til motsatt resultat. Tilfellet kan sammenlignes med uaktsomt drap med bil, som antakelig hadde blitt omfattet av ordningen, om det ikke hadde vært for unntaksregelen i § 1 tredje ledd.

\subsection{3 Årsakssammenheng og beviskrav}

Ingen av sakene er avslått på grunn av manglende årsakssammenheng mellom dødsfallet og den straffbare handlingen, og det fremkommer ikke av noen av vedtakene hvordan vilkåret

\footnotetext{
181 Jf. pkt. 3.2.1.

182 Opplysning fra advokat Tom Sørum. Det var da det falt dom i Ferreira (C-348/98) i EF-domstolen, som klargjorde at alt personlig erstatningsansvar må være dekket av en forsikring.

183 Opplysning fra advokat Jan Gunnar Ness.

184 Opplysning fra Remi Strand ved Kontoret.

185 Se pkt. 3.3.4.4.

186 ENV 2007/3647.

187 ENV 2007/967.
} 
anvendes. Som jeg kommer til nedenfor, er forklaringen sannsynligvis at Kontoret hovedsakelig legger rettens avgjørelse til grunn, og trenger følgelig ikke å ta stilling til dette selv.

Det kreves videre adekvat årsakssammenheng mellom dødsfallet og etterlattes tap. I en sak krevde en far erstatning for tap som følge av at han var kausjonist for sin avdøde sønns lån. Kontoret avslo kravet, da det ikke var nær og påregnelig årsakssammenheng mellom kausjonsansvaret og drapet. ${ }^{188}$ Dette viser at Kontoret selv vurderer årsakssammenheng mellom skaden og det økonomiske tapet.

Det kreves klar sannsynlighetsovervekt for at en straffbar handling etter $\S 1$ er begått, jf. voerstl. $\S 3$ tredje ledd. Beviskravet er ofte benyttet som avslagsgrunn, ${ }^{189}$ men i undersøkelsen er det bare benyttet som avslagsgrunn i $12 \%$ av sakene. Dette kan trolig forklares med at flere drap blir oppklart, og er lettere å bevise enn for eksempel voldtekt. ${ }^{190}$

I et vedtak fremhever Kontoret at «[lo]vens beviskrav er strengere enn det som kreves etter alminnelig erstatningsrett, men ikke så strengt som for domfellelse i en straffesak.» ${ }^{191}$ Kontoret skal i utgangspunktet foreta en selvstendig vurdering av beviskravet. Er gjerningsmannen dømt, legges det imidlertid til grunn at beviskravet er oppfylt. Dette kan belyses med et eksempel hvor Kontoret bemerker at:

«Voldsoffererstatning tilkjennes bare når det foreligger klar sannsynlighetsovervekt for at skadelidte har vært utsatt for en straffbar handling som nevnt foran, jf. voldsoffererstatningslovens $§ 3$ fjerde ledd. Med bakgrunn i domfellelsen legger Kontoret til grunn at vilkåret er oppfylt.»

188 Påklaget til Nemnda som stadfestet vedtaket, jf. ENV 2006/2524.

189 Jf. Ot.prp. nr. 10 (2007-2008) pkt.2.2.

190 Oppklaringsprosenten i 2006 for drap var 91\%, og for voldtekt 30-55\% avhengig av type voldtekt, se http://www.politi.no/pls/idesk/docs/ f1537358626/drapsstatistikk2007.pdf. Se også pkt. 3.2.3.

191 Slik er kravet også forstått i rettspraksis, jf. pkt. 3.5.1. 
Begrunnelsen benyttes gjennomgående hvor gjerningsmannen er drapsdømt. For å få tydeligere frem hvordan Kontoret anvender beviskravet, er det mer interessant med de vedtakene hvor dom ikke foreligger.

Det var 3 saker i undersøkelsen som ikke var oppklart. Da kunne ikke Kontoret basere seg på rettens vurderinger, og sakene kan gi eksempler på hvordan beviskravet anvendes. Et eksempel er hvor Kontoret kom til at beviskravet var oppfylt, fordi den rettsmedisinske undersøkelsen påviste at dødsårsaken skyldtes skuddene i hodet. I de andre sakene, ble også rettsmedisinske undersøkelser tillagt avgjørende vekt som bevistema.

I en henlagt sak kom Kontoret til at det ikke forelå klar sannsynlighetsovervekt, da den rettsmedisinske undersøkelsen ikke påviste en sikker dødsårsak. Nemnda kom til motsatt resultat da de vektla vitneuttalelser og forholdene rundt avdøde. ${ }^{192}$ Det kan se ut til at Kontoret var for strengt når det gjaldt beviskravet. Videre kan en trekke den slutning at en rettsmedisinsk erklæring som ikke er entydig, gjør det vanskeligere for Kontoret å ta stilling til beviskravet.

192 ENV 2007/1364. 


\subsubsection{Sammenfatning}

En samlet betraktning av anvendelsen av vilkåret om straffbar handling, viser at Kontoret ikke foretar selvstendige vurderinger hvis gjerningsmannen er dømt for forsettlig drap. Dette har også støtte i teorien. ${ }^{193}$

Ved handlinger som har preg av vold eller tvang, har Kontoret selv vurdert om handlingen omfattes. Vilkåret anses ikke oppfylt hvor retten har karakterisert handlingen som uaktsom, og den ikke er en utpreget voldshandling. Alternativets innhold skal ha utkrystallisert seg i praksis, ${ }^{194}$ men båt-sakene viser at det kan være tvil rundt enkelte handlinger. Forklaringen på dette kan være at voldsbegrepet rammer vidt, og det kan være uklart hvor grensen for voldsanvendelse går nedad. Dette kan gå på bekostning av hensynet til etterlattes forutberegnelighet.

Det ser likevel ut til at Kontoret har vært konsekvent i sine selvstendige vurderinger, ved at like tilfeller er vurdert likt. Forklaringen på det er at likhetsprinsippet står sentralt i forvaltningen. Prinsippet er for $\varnothing$ vrig et element $\mathrm{i}$ rettssikkerhetsidealet. ${ }^{195} \mathrm{Om}$ forvaltningen følger sin egen praksis, så vil praksisen bli ensartet. For å sikre dette har Kontoret retningslinjer å forholde seg til, og det er også derfor Kontoret tillegger Nemndas vedtak vesentlig vekt. Ensartethet skal forhindre vilkårlighet i forhold til hvilke handlinger som omfattes, ${ }^{196}$ og dette skaper igjen tillit til ordningen.

Videre har undersøkelsen vist at unntaket for bildrap fører til at etterlattes erstatningsrettslige vern ikke blir tilstrekkelig ivaretatt. Det er imidlertid antatt at Justisdepartementet påtar seg ansvaret for krav som ikke utbetales. ${ }^{197}$

193 Jf. Schønning 1992 s. 26.

194 Jf. Ot.prp. nr. 4 (2000-2001) s. 21.

195 Jf. Eckhoff \& Smith 2006 s. 52. Etterlattes rettssikkerhet kommer jeg tilbake til i pkt. 5.

196 Jf. Eckhoff \& Smith 2006 s. 52.

197 Opplysning fra advokat Jan Gunnar Ness. 
Kontoret legger rettens avgjørelser til grunn også når det gjelder beviskravet. At Kontoret generelt er svært tilbøyelige til å legge rettens avgjørelse til grunn, tyder på at Kontoret føler seg sterkt bundet av rettens avgjørelse. Dette kan forklares med at Kontoret tar hensyn til at retten har bedre forutsetninger for bevisvurdering, da bevisførselen i retten som hovedregel er umiddelbar. ${ }^{198}$ Bak dette kan en også si at ønsket om riktige avgjørelser ligger, herunder hensynet til etterlattes rettssikkerhet. Samtidig forenkler det saksbehandlingen, og hensynet til effektivitet ${ }^{199}$ i forvaltningen blir også ivaretatt.

I de fleste tilfeller hvor retten ikke har tatt stilling til saken, har Kontoret likevel tilkjent etterlatte erstatning. ${ }^{200}$ Sentrale bevistema for Kontoret er rettens bevisvurdering og rettsmedisinske erklæringer. Det legges ubetinget til grunn at beviskravet er oppfylt, hvis de rettsmedisinske unders $\varnothing$ kelsene er entydige.

Kontoret er mer tilbakeholden med å konstatere at det er begått et drap der få dokumenter underbygger det, eller den rettsmedisinske unders $\emptyset$ kelsen ikke er klar. Dette kan igjen være et tegn på at Kontoret er forsiktige med å fastslå at det er begått et drap, hvis de ikke er helt sikre.

At Kontoret er «prisgitt» den rettsmedisinske unders $\varnothing$ kelsen, viser viktigheten av at det tas høyde for de ulike beviskravene $\mathrm{i}$ juss og medisin. ${ }^{201}$ Medisinerne opererer i utgangspunktet med et høyere beviskrav for at noe konstateres å være årsak til noe enn det voldsoffererstatningsmyndighetene gjør. Det kan derfor hende at noen tilfeller faller utenfor ordningen, da Kontoret $\mathrm{i}$ realiteten legger medisinernes årsaksvurdering til grunn. ${ }^{202}$ Dette blir satt på spissen der Kontoret må basere seg på rettsmedisinske undersøkelser, og disse ikke er entydige.

\footnotetext{
198 Fremgår av strprl. § 278 sammenholdt med § 296 første ledd.

199 Jf. Frihagen 2003 s. 58.

200 Dette er tilfelle i 9 av 10 saker som ikke er oppklart.

201 Se pkt. 3.2.3.

202 Se eksempelvis ENV 2007/1364 i pkt. 4.3.3.
} 


\subsection{Hvordan utmåles erstatningen?}

\subsubsection{Erstatning for økonomisk tap}

Det er ikke bare viktig at etterlatte blir tilkjent voldsoffererstatning, men også at erstatningen er en reell kompensasjon for tapet deres.

Det er den direkte skadelidte som har krav på dekning av blant annet lidt og fremtidig $\varnothing$ konomisk tap, jf. voerstl. § 1 sammenholdt med $\S 4$. Det kreves mye om andre enn den direkte skadelidte skal få dekket slikt tap. ${ }^{203}$ Undersøkelsen har vist at praksisen ved Kontoret også er restriktiv. I 6 saker har etterlatte foreldre og søsken søkt om dekning av slikt tap. Samtlige søknader er avslått.

Det ble søkt om erstatning for tap av forsørger i 12 saker i materialet, og søkerne fikk det tilkjent i kun 4 av sakene. Søknader er blitt avslått på grunn at tapet ikke var dokumentert, eller fordi tapet dekkes etter yrkesskadeforsikring. Beregningen går jeg ikke nærmere inn på.

Etter voerstl. $\S 7$ dekkes utgifter til begravelsen, og dette ble tilkjent i $16 \%$ av sakene. I et tilfelle ble anførte begravelsesutgifter ikke tilkjent, da søker som avdødes fraskilte ektefelle ikke ble regnet som etterlatt. ${ }^{204}$

Andre utgifter i forbindelse med gravferden ble tilkjent i ca. $12 \%$ av sakene. Det er tilkjent blant annet reiseutgifter, bensinutgifter, og egenandel på forsikring i forbindelse med rydding av avdødes leilighet. Kontoret kom til at advokatutgifter ikke dekkes hvis de omfattes av bistandsadvokatordningen. Det ser ikke ut til at det er satt noen grense for

\footnotetext{
203 Se pkt. 3.4.

204 Separerte omfattes imidlertid, jf. ENV 2006/1030.
} 
summen av utgifter, så lenge de kan dokumenteres. ${ }^{205}$ Dette stemmer overens med den formelle retten, ${ }^{206} \mathrm{og}$ er etter min mening rimelig ut $\mathrm{i}$ fra prinsippet om full erstatning.

\subsubsection{Hvordan oppreisningen utmåles}

\subsubsection{Innledning}

Det kan tilkjennes oppreisning etter voerstl. $\S 6$ til avdødes ektefelle, samboer, foreldre eller barn, jf. $§ 7$ tredje ledd. Oppreisning ble tilkjent i alle innvilgede saker, med unntak av en. Det ser derfor ut til at retten til oppreisning praktiseres som en «skal»- regel i likhet med praksis etter skadeserstatningsloven. ${ }^{207}$ Av de innvilgede sakene i materialet er det for $\emptyset$ vrig tilkjent kun oppreisning i $67 \%$ av sakene. ${ }^{208}$

Ved utmålingen av oppreisningen, er det i de fleste vedtakene henvist til Høyesterettspraksis. Forklaringen ligger i Høyesteretts normering av oppreisningsbeløpet i drapssaker. Kontoret er ikke bundet av rettens avgjørelse, men den er likevel et tungtveiende moment når oppreisningen skal fastsettes. ${ }^{209}$ Av den grunn er det lettere å si noe generelt om oppreisningsnivået, enn ved for eksempel utmåling av økonomisk tap.

\subsubsection{Forholdet til normen for forsettlig drap}

Den veiledende normen for forsettlige drap ble i Knivdrap (Rt. 2001 s. 274) satt til kr 120 000. Undersøkelsen viser at Kontoret legger rettens oppreisningsbeløp til grunn uten

\footnotetext{
205 Tilkjent med summer opp til kr 60000.

206 Jf. pkt. 3.3.3.

207 Jf. pkt. 3.3.4.2 og Lødrup 2005 s. 379.

208 I $33 \%$ av sakene ble det krevd økonomisk tap i tillegg til oppreisning. I ca. $92 \%$ av disse ble søkerne tilkjent sitt anførte tap helt eller delvis.

209 Se bl.a. ENV 2007/855.
} 
nærmere vurdering, hvis gjerningsmannen er domfelt. Dette fremkommer i et av Kontorets vedtak:

«Søkeren ble i tingretten tilkjent oppreisning med kr. 175000 . Kontoret vektlegger rettens avgjørelse og tilkjenner søkeren oppreisning med kr. 175 000, jf. voldsoffererstatningsloven $\S 6$, jf. § 7.»

Slik blir oppreisningsbeløpet utmålt i de fleste tilfeller der retten har tatt stilling til oppreisningsbeløpet. Det er kun i $28 \%$ av vedtakene at Kontoret har foretatt en selvstendig vurdering av oppreisningsbeløpet. ${ }^{210}$ Disse sakene viser i større grad hvordan Kontoret selv utmåler oppreisningen.

Jeg vil begynne med å se på de vedtakene der de etterlatte er tilkjent oppreisning over norm. Dette er tilfelle i $42 \%$ av sakene, ${ }^{211}$ men det er bare i 7 av sakene at Kontoret har foretatt en selvstendig vurdering.

Et eksempel er hvor moren til en jente på 1 år ble drept. Kontoret viste til en avgjørelse i Nemnda, hvor den etterlatte ble tilkjent kr 200000 da han ble frarøvet en omsorgsperson i tidlig alder. ${ }^{212}$ Uten nærmere begrunnelse fant Kontoret det rimelig å legge samme beløp til grunn.

Et annet eksempel er en uoppklart sak der faren til fire barn fra 8- 17 år ble skutt. Kontoret tilkjente kr 200000 til hvert av barna og begrunnet det med følgende:

\footnotetext{
210 Dvs. i 22 av 80 saker hvor det er innvilget oppreisning.

211 Noen ble redusert på grunn av $20 \mathrm{G}$.

212 ENV 2005/248.
} 
«Ved utmålinga av oppreising skal det etter rettspraksis mellom anna leggjast vekt på handlinga si objektive grovhet, skadevaldar si skuld, fornærma si subjektive oppleving av krenkinga og arten og omfanget av dei påførte skadeverknadene, jf. Rt. 2005 s. 289. I ENV 2006/1033 vart det gjeve oppreising med kr 200000 til ei jente då hennar far vart drepen. Kontoret ser hen til praksis og tilkjenner oppreising med kr 200 000.»

Begge vedtakene er eksempler på at Kontoret støtter seg til og underbygger sine vurderinger med avgjørelser fra Nemnda, når de foretar selvstendige vurderinger. Nemndas praksis er således viktig for Kontorets rettsanvendelse.

I $23 \%$ av sakene er etterlatte tilkjent oppreisning i samsvar med norm. I disse sakene, med unntak av to, er gjerningsmannen dømt i retten. Et eksempel er en sak som ikke var avgjort. Kontoret tilkjente kr 120000 til de etterlatte barna, som begge var under 5 år på drapstidspunktet. Samme beløp ble tilkjent samboeren til en kvinne som ble skutt og drept, «selv om Knivdrap (Rt. 2001 s. 274) gjaldt en mor som mistet sin sønn ved knivdrap». Vedtakene bekrefter at Kontoret anser normen som veiledende, ${ }^{213}$ og at den blir tillagt avgjørende vekt.

Vedtakene hvor det er tilkjent oppreisning i samsvar med norm, gjelder ikke like tilfeller, men de etterlatte er likevel tilkjent samme beløp. Det vil si at Kontoret ikke har funnet særlige grunner til å fravike normen. Ses vedtakene i sammenheng med eksemplene hvor etterlatte ble tilkjent oppreisning over norm, kan en stille spørsmålstegn ved at små barn tilkjennes over norm i noen vedtak, mens andre små barn ble tilkjent kr 200 000. Kontorets utmåling kan her virke tilfeldig. Dette er imidlertid et kun eksempel, og ikke en tendens. ${ }^{214}$

213 Jf. pkt. 3.3.4.3.

214 Vedtakene hvor det ble tilkjent kr 200 000, ble fattet noen måneder etter at små barn ble tilkjent kr 120 000. Det er mulig Kontoret har fått en ny retningslinje etter de første vedtakene. 
Det er tilkjent oppreisning under norm i $35 \%$ av sakene. I en henlagt sak søkte avdødes barn om oppreisning. I vedtaket ble det bemerket følgende i tilknytning til Knivdrap

(Rt. 2001 s. 274):

«Denne avgjørelsen gjelder ikke etterlatte barn, men den kan sies å gi en viss veiledning på hvor oppreisningsbeløpet bør ligge. I Rt. 2004 s. 1324 fremgår det at alder og tilknytning er relevante momenter.. Her ble avdødes foreldre tilkjent kr 100000 i oppreisning...

I nærværende sak er avdødes barn godt voksne. Søker har således ikke mistet en omsorgsperson på samme måte som et lite barn ville ha gjort. Kontoret finner det etter dette skjønnsmessig å tilkjenne kr 100000 i oppreisning.»

Med bakgrunn i likhet med saksforholdet i Haglegevar (Rt. 2004 s. 1324), tilkjente Kontoret oppreisning under norm. Alder og tilknytning er derfor momenter som Kontoret tar hensyn til ved vurderingen av fravikelse av normen.

Oppreisningsnivået oppsummeres i tabellen nedenfor, og den angir hvordan oppreisningsbeløpene forholder seg til normeringen.

\section{Tabell 2. Oversikt over oppreisningsnivået}

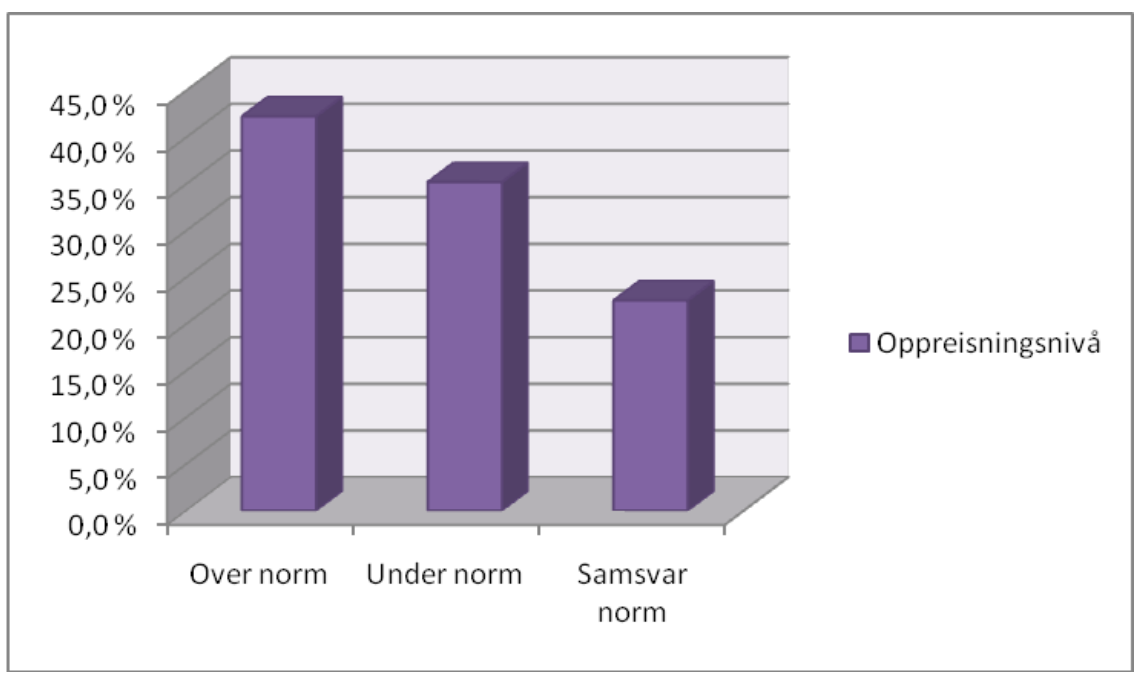


Tabellen viser at det er flest etterlatte som er tilkjent oppreisning over norm. Det betyr at retten og Kontoret i flere tilfeller har funnet særlig grunn til å fravike normen. Praksis viser at barn, på grunn av momentene alder og tilknytning, ofte tilkjennes oppreisning over norm. Etter dette kan det antas at flest etterlatte er barn.

Dette stemmer overens med frekvensfordelingen av etterlatte. Det er for eksempel dobbelt så mange etterlatte barn av avdøde som foreldre. Det er $75 \%$ av barna under 18 år som er tilkjent oppreisning over norm, og de barna som er tilkjent under norm er voksne barn etter avdøde. Foreldre og ektefeller er tilkjent oppreisning i samsvar med norm eller under norm.

\subsubsection{Forholdet til normen for uaktsomt drap}

Det er 33 av de 114 vedtakene som gjelder uaktsomme drap. I 23 av disse er det ikke gitt oppreisning til søkerne. Dette har sammenheng med at de fleste uaktsomme drapene er bildrap som faller utenfor ordningen.

Ved uaktsomme drap er normen $\mathrm{kr} 75000 .^{215}$ I vedtakene i praksisundersøkelsen er det tilkjent oppreisning for uaktsomme drap med opp til kr 100 000. Kontoret har ikke foretatt en selvstendig vurdering av kravet i noen av sakene. Jeg gir derfor bare noen eksempler for å vise nivået for uaktsomt drap generelt.

I 3 av vedtakene ble søkerne tilkjent oppreisning i samsvar med normen. Et eksempel er hvor de etterlattes far døde etter forsettlig forgiftning etter strl. $§ 153$. Skadevolderne ble dømt til å betale oppreisning med kr 75000 . Kontoret viste til momentene som skal vektlegges etter Sprengladning (Rt. 2005 s. 289), og satte samme beløp som retten. ${ }^{216}$

\footnotetext{
215 Jf. Lekestativ (Rt. 2006 s. 61).

216 Ved forsettlige overtredelser av strl. § 153, tar altså retten utgangspunkt i normen for uaktsomt drap.
} 
I 7 av sakene er det tilkjent oppreisning over kr 75 000. Dette gjelder grovere tilfeller av uaktsomme drap. Det ser derfor ut til at retten setter oppreisningsbeløpet høyere der det er mer graverende tilfeller enn «normaltilfellet» av uaktsomt drap. I saker hvor det er tilkjent oppreisning under norm, er det momentene alder og tilknytning som er blitt tillagt vekt.

\subsubsection{Hvilke virkninger har den øvre beløpsgrensen for etterlatte?}

I en drapssak kan det være flere etterlatte som søker om voldsoffererstatning. Samlet vil erstatningskravene deres kunne overstige den $\emptyset$ vre beløpsgrensen i voerstl. $\S 11$. En hypotese er at etterlatte kommer dårligere ut enn andre grupper av erstatningsberettigede på grunn av beløpsgrensen.

Justisdepartementet gjennomgikk sakene som har nådd beløpsgrensen i forbindelse med endringene i voldsoffererstatningsloven, og kom til at materialet var for spinkelt til å endre grensen.

Kontoret har behandlet 48 saker som har nådd $20 \mathrm{G}$, hvorav 26 er etterlattesaker. Samtlige saker er behandlet etter voldsoffererstatningsloven, og i alle sakene er det to eller flere etterlatte.

I sakene er det kun 5 etterlatte som fikk innvilget erstatningskravet sitt fullt ut. De fleste av disse søkte kun om oppreisning. Det kan antas at når etterlatte krever noe i tillegg til oppreisning, blir kravet bare delvis innvilget. De resterende 21 sakene er delvis innvilget på grunn av at 20 G-grensen ble overskredet og erstatningen måtte derfor reduseres. Dette gir et klart bilde på at grensen fører til at mange av etterlatte ikke får erstattet sitt tap etter avdøde. 
Av et vedtak fremkommer det hvordan Kontoret beregner reduksjonen på grunn av 20 Ggrensen:

«I nærværende sak er erstatning og oppreisning til de etterlatte utmålt med til sammen kr 1516430.

Søkers andel av dette utgjør 61,1 prosent. Søker tilkjennes derfor 61,1 prosent av 20 G, som tilsvarer kr 816 443. Av dette utgjør kr 200000 oppreisning og kr 616443 erstatning for økonomisk tap.»

I ca. $71 \%$ av sakene hvor det foreligger dom fra retten, er de etterlatte tilkjent mindre enn det de ble tilkjent i retten. For etterlatte kan det være vanskelig å forsone seg med at de ikke får det de i utgangspunktet er tilkjent.

I 2 saker ble erstatningsbeløpet det samme som i dommen. Lik sum er tilkjent i en sak der avdødes foreldre kun søkte om oppreisning. ${ }^{217}$ I 5 saker ble de etterlatte tilkjent mer enn i retten. Når etterlatte har fått tilkjent mer enn i retten, så har dette gått ut over de andre etterlatte i saken. Et eksempel er hvor avdødes mor ble tilkjent høyere oppreisning av Kontoret enn i retten. ${ }^{218}$ Avdødes datter fikk imidlertid redusert sitt krav på erstatning med ca. $\mathrm{kr} 660000$.

Tabellen nedenfor gir en oversikt over gruppen av etterlatte, og hvorvidt de har fått innvilget kravet sitt fullt ut, eller om det er blitt redusert på grunn av beløpsgrensen.

217 Avdødes barn på henholdsvis 8 år og 1 år søkte imidlertid i tillegg om forsørgertap, og fikk redusert kravet sitt betydelig på grunn av beløpsgrensen.

218 For øvrig eneste eksempel på at Kontoret har fraveket rettens vurdering. 
Tabell 3. Oversikt over etterlatte og i hvilken grad de har fått innvilget kravet sitt fullt ut.

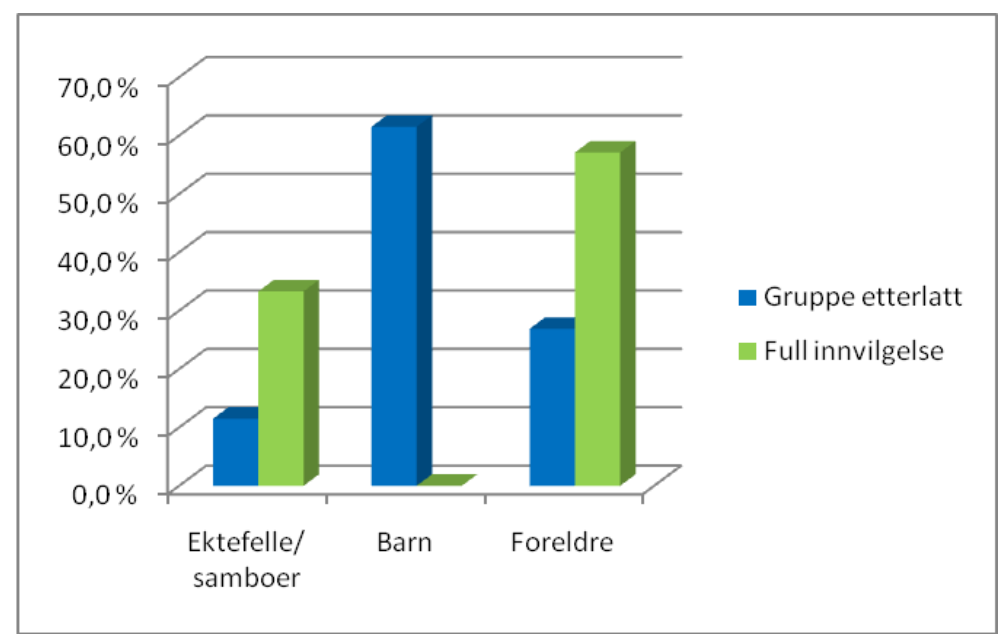

I 20 G-sakene er det $62 \%$ av de etterlatte som er avdødes barn og de utgjør derfor den største gruppen av etterlatte. Ingen av dem har fått innvilget kravet sitt fullt ut.

Det er $27 \%$ av de etterlatte som er avdødes foreldre, og $80 \%$ av dem har fått innvilget sitt anførte tap. Det var $11 \%$ av de etterlatte som var avdødes ektefelle, og der er det kun én som har blitt tilkjent krevd erstatning.

Av de etterlatte er det barna i alderen 0-5 år som utgjør den største gruppen av etterlatte på $31 \%$. Hvis man ser på personer under 18 år utgjør disse $47 \%$ av de etterlatte. Undersøkelsen viser at jo yngre barna er, desto mer «taper» de på grunn av 20 Ggrensen. ${ }^{219}$ Dette kan blant annet ha sammenheng med at kravet for tap av forsørger er større for yngre enn for eldre barn.

219 Bl.a. ble et lite barns erstatningskrav redusert med ca. kr 1300000. 
En kan med i bakgrunn i dette stille spørsmål ved om etterlattes vern blir tilstrekkelig ivaretatt. Hensynene som begrunner grensen er at staten skal kunne forutse sine utgifter og forenkle saksbehandlingen. Ut i fra undersøkelsen ser det ut til at grensen i stor grad rammer etterlatte, og spesielt etterlatte barn. Dette er en gruppe som er blitt utsatt for stor belastning ved at en nærstående er blitt drept. Selv om ordningen er subsidiær, må det antas at det ikke var lovgivers intensjon at grensen i hovedsak skulle ramme små barn.

Ved lovfestingen av voldsoffererstatningsordningen, ble det besluttet å heve grensen til 20 $\mathrm{G}$ for at «også de med de mest omfattende skadene i de fleste tilfeller blir dekket fullt ut». ${ }^{220}$ I realiteten fører imidlertid grensen fortsatt til at den rammer spesielt en gruppe erstatningsberettigede. En heving av grensen synes derfor hensiktsmessig ut i fra prinsippet om full erstatning og rettferdighetshensynet. ${ }^{221}$

\footnotetext{
220 Jf. Ot.prp. nr. 4 (2000-2001) s. 28.
}

221 Jf. pkt. 3.4. 


\subsubsection{Sammenfatning}

Unders $ø$ kelsen viser at Kontoret legger rettens erstatningsbeløp til grunn der erstatningskravet er pådømt i retten.

Det er få saker hvor Kontoret har vurdert oppreisningsbeløpet selv, slik at en vanskelig kan trekke tendenser ut av disse sakene. Der det er foretatt selvstendige vurderinger, ser det likevel ut til at utgangspunktet er Høyesteretts normering og praksis. Dette er i tråd med forarbeidene, ${ }^{222}$ hvor det anføres at oppreisningsnivået bør følge domstolenes.

Av unders $ø$ kelsen kan en trekke den slutningen at Kontoret ikke foretar vurderinger løsrevet fra domstolenes vurderinger. At Kontoret tilkjenner det samme som i retten, forenkler saksbehandlingen. Samtidig ivaretas hensynet til etterlattes forutberegnelighet, og gjør det lettere for dem å innfinne seg med resultatet. Videre har det støtte i rettferdighetshensyn. Det kan antas at etterlatte ville følt det urettferdig, om de hadde blitt tilkjent mindre enn $\mathrm{i}$ retten. Ulike beløp kan riktignok forsvares ut $\mathrm{i}$ fra ulikheter $\mathrm{i}$ regelsettene. Men hvis Kontoret konsekvent kommer til en annen avgjørelse enn retten, kan dette svekke tilliten til rettssystemet ved at det sås tvil om hvilket beløp som egentlig er det riktige. Videre er utmålingsreglene nært knyttet til skadeserstatningsloven. Dette i seg selv tilsier at beløpet ikke bør bli så ulikt rettens beløp.

Ellers vektlegger Kontoret utmålingspraksis fra Nemnda om de finner støtte i den. Dette bidrar til et noenlunde likt oppreisningsnivå for like tilfeller.

Jeg framsatte en hypotese om at beløpsgrensen ville ramme etterlatte. Unders $ø$ kelsen avdekket nettopp dette. Da hjelper det lite at man i utgangspunktet er blitt tilkjent det samme som i retten.

222 Jf. Ot.prp. nr. 4 (2000-2001) s. 29. 
Grunnen til at grensen rammer etterlatte er at de ofte er flere etter avdøde. Jo flere de er, desto høyere blir deres samlede erstatningskrav, og jo lettere nås beløpsgrensen. Funnene avdekker at grensen slik den er per i dag, i flere tilfeller er for lav til at alle etterlatte oppnår dekning for kravet sitt.

Utgangspunktet er at det skal tilkjennes full erstatning, men ordningen kan likevel operere med beløpsgrenser. ${ }^{223}$ Undersøkelsen har vist at beløpsgrensen fratar flere etterlatte muligheten for full erstatning. Jeg kommer tilbake til beløpsgrensen under de avsluttende betraktningene under punkt 5 .

223 Jf. Ot.prp. nr. 10 (2007-2008) s. 29. 


\section{Samlende betraktninger}

\subsection{Innledning}

Avslutningsvis vil jeg plassere noen av funnene i et større rettslig perspektiv. I punkt 5.2 drøftes det om ordningen imøtekommer lovens formål og etterlattes forventninger til den. Herunder behandles derfor etterlattes rettssikkerhet i punkt 5.2.1, og etterlattes møte med ordningen under punkt 5.2.2. I punkt 5.2.3 settes fokuset på om alle voldsofre har lik mulighet til å få dekning for sitt tap, og i punkt 5.2.4 knyttes det noen bemerkninger til offerrollen. Avslutningsvis vurderes etterlattes vern i et rettspolitisk perspektiv, herunder hvilken betydning reglene i endringsloven kan få for etterlatte.

5.2 Imøtekommer ordningen lovens formål og etterlattes forventninger til den?

\subsubsection{Ordningens betydning}

Bakgrunnen for voldsoffererstatningordningen, kan forklares ut i fra samfunnsforholdenes innvirkning på retten. Volden er blitt råere og den rammer mer tilfeldig. Samfunnet har blitt mer oppmerksom på ofrene for volden, og problemet er satt på «dagsorden». Slike endringer $i$ normer og holdninger $i$ samfunnet, kan ha vært en viktig «premissleverandør» ${ }^{224}$ for lovgiverne da de lovfestet voldsoffererstatningsordningen.

Formålet med voldsoffererstatningen er å erstatte etterlattes tap. Følgelig er dette de forventninger etterlatte får til ordningen. En kan derfor stille spørsmålet om voldsoffererstatningsordningen imøtekommer lovens formål, og etterlattes forventninger til den.

224 Jf. Mathiesen 2005 s. 105. 
Undersøkelsen kan belyse ordningens betydning for etterlatte. Den viser at det er begått 9 forsettlige drap i 2005. I følge Kripos’ drapsstatistikk ble det til sammen begått 29 drap i 2005..$^{225}$ Det innebærer at nesten en tredel av skadevolderne ikke har utbetalt erstatning til de etterlatte. Dette tyder på at skadevolderne ofte ikke utbetaler erstatningen. At skadevolder ikke utbetaler erstatningen, er hovedbegrunnelsen bak voldsoffererstatningsordningen. Funnene har vist at dette er realiteten, og føyer seg således inn i det som er bevist og lagt til grunn i forarbeidene. ${ }^{226}$

\subsubsection{Etterlattes rettssikkerhet}

Et element i rettssikkerhetsidealet er at like tilfeller skal behandles likt. ${ }^{227}$ I prinsippet kan Kontoret kan komme til et annet resultat enn retten, ${ }^{228}$ på grunn av ulikheter i regelsettene og ulik vektlegging av hensyn. På bakgrunn av undersøkelsen kan det imidlertid antas, at Kontoret vil legge rettens avgjørelse til grunn der den har tatt stilling til saken. Dette bidrar til at saker kan få samme resultat i retten som etter voldsoffererstatningsordningen. Ved at domstolene og forvaltningen anvender retten på samme måte, forhindres rettslig pluralisme. $^{229}$ Dette fører igjen til at etterlattes rettssikkerhet ivaretas. ${ }^{230}$ Videre ivaretas hensynet til etterlattes forutberegnelighet, og dette forenkler deres møte med forvaltningen.

Av undersøkelsen ser det ut til at Kontorets selvstendige vurderinger er konsekvente, og at like tilfeller behandles likt. En ensartet praksis er viktig for etterlattes rettssikkerhet. Slik jeg ser det, er dette et utslag av at retningslinjene Kontoret jobber etter i drapssaker, fungerer godt i praksis. Videre er saksbehandlerne jurister, som i likhet med domstolene,

\footnotetext{
225 http://www.politi.no/pls/idesk/docs/f1537358626/drapsstatistikk2007.pdf.

226 Jf. Ot.prp. nr. 4 (2000-2001) s. 5.

227 Jf. Eckhoff og Smith 2006 s. 50.

228 Se bl.a. pkt. 3.3.1.

229 Begrepet «rettslig pluralisme» forstås på ulike måter, jf. Mathiesen 2005 s. 235. I avhandlingen forstås begrepet som at ulike grupper rettsanvendere tolker og anvender retten på ulik måte.

230 Jf. Mathiesen 2005 s. 241 hvor det antas at rettslig pluralisme kan være en fare for rettssikkerheten.
} 
benytter juridisk metode. Dette er i seg selv et viktig argument for at etterlattes sikkerhet blir ivaretatt. På den måten skal etterlatte i utgangspunktet være i «trygge hender» uavhengig av om de får erstatning direkte fra skadevolder eller fra staten. Samtidig er juristene sosialisert gjennom studiet, og således opplært til å løse rettsspørsmål likt. ${ }^{231}$ Dette kan også bidra til en ensartet saksbehandling.

Ytterligere et moment er at voldsoffererstatningslovens utmålingsregler i stor grad svarer til skadeserstatningslovens. Retten og voldsoffererstatningsmyndighetene bør derfor komme til noenlunde samme resultat. Rettssikkerheten ivaretas også ved at Kontoret legger til grunn at retten har bedre forutsetninger for å vurdere bevis, og således komme frem til riktig resultat.

\subsubsection{Etterlattes møte med juristene}

At Kontorets saksbehandlere er jurister, har også en annen side. For etterlatte kan det være belastende å måtte søke om voldsoffererstatning. Videre kan det oppleves som en tilleggsbelastning om de må argumentere mot et offentlig kontor med jurister. Saksbehandlernes oppgave er ikke å være motpart, men å utmåle riktig erstatning. Juristers måte å argumentere på, kan likevel oppfattes som vanskelig å forstå og dermed argumentere mot, ${ }^{232}$ og juristene kan oppfattes som en «overmakt». Samtidig kan følelsen av å møte motstand forsterkes ved at det er regler i loven som virker urimelige.

I et vedtak uttrykte en søker frustrasjon over Kontorets begrunnelser. Søker opplevde Kontorets «skarpsindige» jurister som motpart, og stilte spørsmål ved om dette var meningen bak ordningen. Dette er et tegn på at søkere oppfatter seg selv som den svakere part, som igjen kan nødvendiggjøre juridisk bistand.

\footnotetext{
231 I den retning Mathiesen s. 130 og s. 164.

232 Jf. Mathiesen 2005 s. 82.
} 
Bistandsadvokatordningen kan avhjelpe dette. Har for eksempel avdødes foreldre fått oppnevnt bistandsadvokat, antas det at denne skal bistå med å utforme søknaden om voldsoffererstatning. ${ }^{233}$ Dekning av advokatutgifter var anført i ett vedtak i unders $\varnothing$ kelsen, og Kontoret fant at utgiftene ble dekket gjennom bistandsadvokatordningen. At få etterlatte anførte slikt tap, kan mest naturlig forklares med at mange hadde bistandsadvokater. Alternativt kan etterlatte ha søkt på egen hånd, eller ikke anført advokatutgiftene som et tap. Bistandsadvokatordningen ble for øvrig utvidet i juli 2008, slik at flere etterlatte skal få bistand. ${ }^{234}$ At etterlattes rettigheter støttes av slike prosessuelle bestemmelser, kan bidra til å styrke deres stilling. ${ }^{235}$

Direkte skadelidte kan få dekket advokatutgifter gjennom voerstl. $\S 44^{236}$ Etter endringsloven kan etterlatte tilkjennes erstatning etter voerstl. $\S 4$, og etterlatte som ikke har bistandsadvokat kan dermed få dekket advokatutgifter. At saksbehandlerne er jurister, kan derfor få mindre betydning for etterlatte.

En annen side av behovet for juridisk bistand, er at det kan være en barriere i seg selv å oppsøke en advokat. Advokatene kan oppleves som en fjern og eksklusiv yrkesgruppe, ${ }^{237}$ og det kan det være vanskelig å orientere seg i advokatmengden. Kontorets nettsider gir imidlertid en oversikt over advokater som arbeider med voldsoffererstatning.

\subsubsection{Har voldsofre og etterlatte lik mulighet for dekning av tap?}

Voldsoffererstatningsordningen gir uttrykk for at de som ikke får erstatning fra skadevolderen, får dekket sitt tap av staten. Selv om staten opptrer som giver, er det ikke

\footnotetext{
233 Jf. Bistandsadvokat (Rt. 1996 s. 293).

234 Jf. NOU 2006: 10 s. 55 og strprl. $§ 107$ a andre og tredje ledd.

235 I den retning Mathiesen s. 76.

236 Jf. ENV 2005/2028.

237 Jf. Mathiesen 2005 s. 64.
} 
gitt at dette gjøres på en rettferdig måte. ${ }^{238}$ Det må skilles mellom realiseringen av lovens formål og etterlevelse av loven. ${ }^{239}$

Undersøkelsen viser at den reelle retten fungerer tilfredsstillende. Fra et rettssosiologisk perspektiv er det ikke «landskapet» loven havner i som begrenser etterlattes erstatningskrav, ${ }^{240}$ men lovens egne regler. Unders $\varnothing$ kelsen viser at blant annet lovens $\varnothing$ vre beløpsgrense, som i utgangspunktet gjelder alle, rammer etterlattegruppen i halvparten av sakene. Dette er et eksempel på at retten skaper troverdighet ved å etablere en voldsoffererstatningsordning, ${ }^{241}$ men at loven har en tilslørende funksjon ved at beløpsgrensen i realiteten rammer bestemte grupper. ${ }^{242}$ Etterlatte har derfor i realiteten ikke lik mulighet til å oppnå dekning for kravet sitt som andre voldsofre.

Erstatningsrettens formål er gjenopprettelse. Den kan derfor virke kumulerende, ved at skadelidte som før skaden hadde høy inntekt skal få igjen mye, og de som hadde lite skal få igjen like lite. ${ }^{243}$ Denne «Matteus-effekten» ${ }^{244}$ er også debattert rundt tap av forsørgerutmålingen. Det er anført at blant annet forsikringsutbetalingene, som etter

skl. § 3-1 «kan» fradras, medførte at etterlatte i Bastrup (Rt. 1998 s. 639) ble overkompensert. $^{245}$

I forhold til voldsoffererstatning, fremkommer det imidlertid av unders $\varnothing$ kelsen at oppreisning er den viktigste erstatningsposten for etterlatte, og oppreisningen er forholdsvis standardisert. Videre skal forsikringsytelser fradras etter voerstl. § 9. Dette kan det tyde på at voldsoffererstatningen ikke har gitt noen «Matteus-effekt» i denne unders $\emptyset$ kelsen.

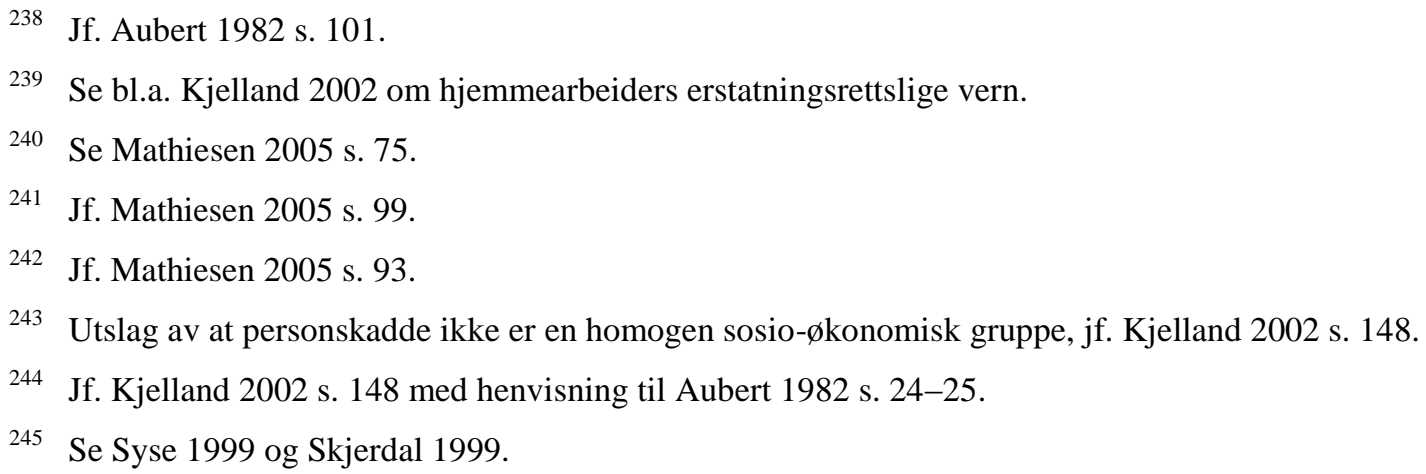




\subsubsection{Offerrollen}

Fra et rettssosiologisk perspektiv kan det være en problemstilling at ordningen kalles erstatning til voldsofre. Offerrollen er ikke ukomplisert, og det kan synes som et paradoks at staten åpner for en slik rolle som på sett og vis appellerer til det maktesløse. ${ }^{246}$ At personer kalles ofre kan medføre at de automatisk inntar en offerrolle, og at andre oppfatter dem som ofre. Offerbegrepet kan således produsere et bilde av personer som svake og passive. Det kan være problematisk om etterlatte må gå inn i en offerrolle for å få erstatning.

På den andre siden kan offerbegrepet sette fokus på samfunnsproblem, og virke som en politisk brekkstang. At det er etablert en ordning for voldsofre og deres etterlatte, har utvilsomt satt fokus på volden i samfunnet og dens ofre.

Etterlatte kalles ikke offer på lik linje med for eksempel voldtektsoffer. De omfattes likevel av voldsoffererstatningsordningen, og det er kanskje ikke usannsynlig at etterlatte inntar en offerrolle for å bli tilkjent voldsoffererstatning. Noen kan nok føle at de må argumentere for tapet de har lidt og hvilken belastning de har gjennomgått, for at kravet deres skal bli hørt. Når loven begrenser etterlattes rett til voldsoffererstatning, kan de i tillegg føle seg som offer for ordningen, og på den måten oppfatte seg selv som offer i dobbelt forstand. Om voldsoffererstatningsordningen gir etterlatte den støtten de trenger, vil det etter min mening kunne være lettere for dem å legge «offerrollen» bak seg.

246 Opplysning fra Hedda Giertsen. 


\subsection{Rettspolitiske betraktninger}

\subsubsection{Lovens begrensninger}

Ved lovfestingen av voldsoffererstatningsloven, ble to prinsipper slått fast. For det første skal staten dekke det tapet skaden påfører, og for det andre står voldsofre i en annen stilling enn andre skadelidte. ${ }^{247}$ Om lovgiver allerede da hadde sett mer spesifikt på etterlattes rettigheter, hadde man etter min mening kunne forutsett lovens begrensninger, og at den ikke ivaretar etterlattes vern tilstrekkelig. Etterlatte bør kunne få dekket økonomisk tap på lik linje med andre voldsofre. Og beløpsgrensen bør heves betraktelig for at den ikke skal ramme etterlatte spesielt. ${ }^{248}$

Siden loven ble vedtatt, har begrensningene vært gjenstand for kritikk. Det kan tyde på at reglene i loven har kommet i «utakt» med folks rettsoppfatning. Dette kan svekke tilliten til ordningen, og det kan antas at kritikken er bakgrunnen for endringene som er foretatt $\mathrm{i}$ loven.

\subsubsection{Bedre ivaretakelse av etterlattes vern?}

Endringene i voldsoffererstatningsloven kom med bakgrunn i Soria Moria-erklæringen, for blant annet å styrke etterlattes rettigheter. ${ }^{249}$ For det første er den erstatningsbetingende handlingen endret til «straffbare handlinger som krenker livet, helsen eller friheten», jf. voerstl. § 1. Ordlyden samsvarer bedre med strafferettslig terminologi, og formålet er at flere handlinger skal omfattes. ${ }^{250}$ Det er ikke lenger tale om vold eller tvang i snever forstand. ${ }^{251}$ Slik jeg ser det bør nå død forvoldt ved uaktsom forgiftning omfattes, ${ }^{252} \mathrm{da}$ dette kan anses som en handling som krenker livet eller helsen.

\footnotetext{
247 Jf. Innst. O. nr. 46 (2000-2001) pkt. 3.1.1.

248 Se pkt. 3.4.

249 Jf. Ot.prp. nr. 10 (2007-2008) s. 7.

250 Jf. Ot.prp. nr. 10 (2007-2008) s. 14.

251 Jf. Ot.prp. nr. 10 (2007-2008) s. 39.
} 
For det andre er voerstl. $\S 7$ tredje ledd endret, slik at etterlatte kan tilkjennes erstatning etter voerstl. $\S 4$, da de kan lide økonomisk tap i tillegg til gravferdsutgifter og tap av forsørger. ${ }^{253}$ Videre er det urimelig at etterlatte ikke får tilkjent erstatning som domstolen kan ha tilkjent dem. ${ }^{254}$ I følge forarbeidene må etterlatte ha lidd en personskade som følge av dødsfallet:

«Skaden vil typisk være en psykisk skade...vil en slik psykisk skade - når den er dokumentert vanligvis tilfredsstille kravet til adekvat årsakssammenheng. Spørsmålet om, og i tilfelle i hvilken grad, det aktuelle økonomiske tapet står i en adekvat årsakssammenheng til den straffbare voldshandlingen vil måtte avgjøres konkret av voldsoffererstatningsmyndighetene.» ${ }^{255}$

Etter min mening fører endringen utvilsomt til bedre ivaretakelse av etterlattes vern. Det er imidlertid viktig å være oppmerksom på, at etterlatte er fjernere i årsaksrekken enn direkte skadelidte. Dette vil få betydning for kravet til årsakssammenheng.

Voerstl. $§ 7$ siste punktum, gir nå sфsken ${ }^{256}$ i særlige tilfeller rett til slik erstatning som andre etterlatte. Det etableres ikke et rettskrav, da det skal avgjøres skjønnsmessig. ${ }^{257}$ At det kreves et sarlig tilfelle tilsier at det skal mye til for at erstatning tilkjennes. Som eksempel nevnes i forarbeidene tilfeller der barn blir drept og søsknene avbryter utdanning på grunn av personskade som følge av dødsfallet. ${ }^{258}$

\footnotetext{
252 Jf. pkt. 4.3.2.2.

253 Jf. Ot.prp. nr. 10 (2007-2008) s. 18.

254 Jf. Ot.prp. nr. 10 (2007-2008) s. 16.

255 Ot.prp. nr. 10 (2007-2008) s. 19.

256 Søsken er ikke etterlatt etter skadeserstatningsloven.

257 Jf. Ot.prp. nr. 10 (2007-2008) s. 17.

258 Jf. Ot.prp. nr. 10 (2007-2008) s. 17. Dette var tilfelle med Marte Bastiansen. A være avdødes søster og ikke bli ansett som etterlatt, var i seg selv veldig belastende.
} 
Skadeserstatningsloven er ikke klar på om etterlatte som i voerstl. § 7, har krav på erstatning fra skadevolder. ${ }^{259}$ Spørsmålet avgjøres konkret av domstolene, og alminnelig erstatningsrett er noe dynamisk hva gjelder dette. ${ }^{260}$ Denne utvidelsen kan derfor etablere et videre erstatningsansvar for staten enn for skadevolder. ${ }^{261} \mathrm{Om}$ dette bemerker departementet:

«Dette vil innebære et brudd på prinsippet om at voldsoffererstatningsordningen er subsidiær i forhold til skadevolderens personlige ansvar. Departementet mener at hensynet til skadelidte må veie tyngre.» ${ }^{262}$

Da etterlatte kan være bedre sikret etter voldsoffererstatningsloven enn skadeserstatningsloven, ${ }^{263}$ kan det legges til grunn at etterlattes erstatningsrettslige vern ivaretas.

I følge forarbeidene bør ikke voldsoffererstatningsmyndighetene redusere erstatning for $\emptyset$ konomisk tap som er tilkjent i domstolene. ${ }^{264}$ Dette vil kunne svekke domstolens legitimitet, da voldsofre og etterlatte får en berettiget forventning om beløpet de tilkjennes av domstolene. ${ }^{265}$ Undersøkelsen viste at Kontoret ikke tilkjente mindre enn retten, med unntak av $20 \mathrm{G}$-sakene og søknader om erstatning etter voerstl. $\S 4$. Dette viser at hensynet til etterlattes forventninger og domstolens utmåling, tillegges vesentlig vekt i praksis.

\footnotetext{
259 Jf. Ot.prp. nr. 10 (2007-2008) s. 18.

260 Jf. Brath 2007 note 24.

261 Jf. Ot.prp. nr. 10 (2007-2008) s. 18.

262 Ot.prp. nr. 10 (2007-2008) s. 18.

263 Det kan ikke søkes regress hos skadevolderen for den delen av erstatningen som går lenger, jf. Innst. O. nr. 25 (2007-2008) punkt 1.2.3.

264 Jf. Ot.prp. nr. 10 (2007-2008) s. 29.

265 Jf. Ot.prp. nr. 10 (2007-2008) s. 30.
} 
Praksisen om at et dødsfall regnes som ett skadetilfelle etter $\S 11$, ble kodifisert i voerstl. $§ 7$ fjerde ledd. ${ }^{266}$ Hensynet til berettigede forventninger tilsier at beløpsgrensen er vanskelig å forstå for etterlatte. De kan oppleve at beløpsgrensen «straffer» dem fordi at de er flere etterlatte. Departementet fant at erfaringsgrunnlaget var for lite til å endre beløpsgrensen, og viser videre til ordningens subsidiære karakter:

«Det er ikke gitt at staten skal tre inn og erstatte hele det tapet skadelidte påføres. Selv om det vil kunne oppstå et tap som overskrider maksimumsbeløpet, vil erstatningsordningen i alle fall innebære en betydelig forbedring av ofrenes stilling. ${ }^{267}$

Justiskomiteen ba departementet om å gjennomgå ordningen frem til revidert Statsbudsjett i 2008. ${ }^{268}$ Etter det reviderte statsbudsjettet ble det heller ikke foretatt endringer.

I oktober 2008 ble det i Statsbudsjett for 2009 foreslått å endre grensen til $40 \mathrm{G},{ }^{269}$ for blant annet å bedre etterlattes stilling. Det skal fremmes en proposisjon i løpet av høsten 2008, og økningen skal tre i kraft fra 1. juli 2009. ${ }^{270}$ Økningen vil sikre etterlatte større grad av dekning, og dermed bedre ivaretakelse av deres erstatningsrettslige vern. Undersøkelsen av 20 G-sakene viste imidlertid at flere etterlatte ble tilkjent mer enn $40 \mathrm{G}$ i retten. Dette innebærer at det fortsatt er etterlatte som kan berøres av grensen.

Hvis dette skal unngås, kan voerstl. $§ 11$ endres slik at et dødsfall anses som et skadetilfelle overfor hver enkelt etterlatt. Gode grunner taler for en slik løsning, da problematikken rundt etterlatte og beløpsgrensen løses automatisk. Selv om det opereres med en beløpsgrense, så vil i alle fall etterlatte stå på lik linje med andre voldsofre.

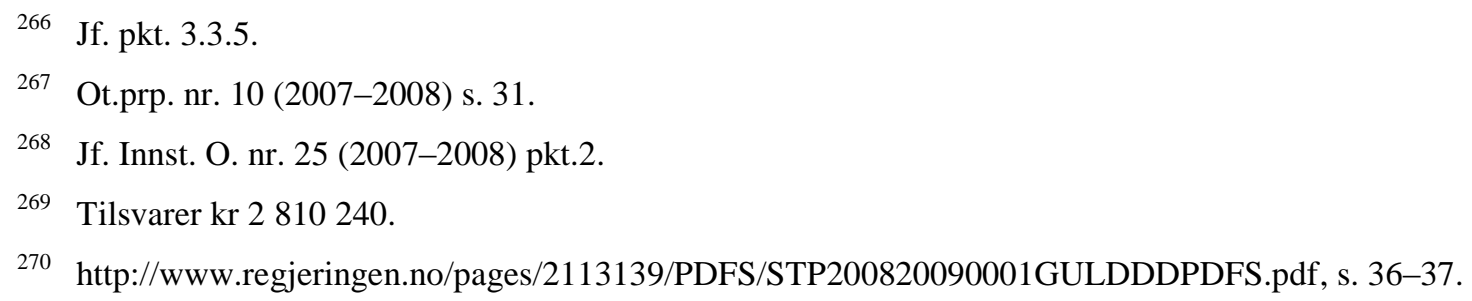


Alternativt kan beløpsgrensen oppheves og bestemmelsen kan heller lovfeste en rett til å bli tilkjent samme beløp som $i$ retten. ${ }^{271}$ Alternativet kan forsvares ut $i$ fra at voldsoffererstatningsloven er så nært knyttet til skadeserstatningsloven, at resultatet bør bli det samme etter begge ordningene. Videre vil alle voldsofre sikres lik rett til erstatning, og hensynet til forutberegnelighet, rettferdighet og forenkling av saksbehandlingen er tungtveiende hensyn. Etter min mening er dette et godt alternativ.

Jeg trekker likevel i retning av å opprettholde en beløpsgrense. Voldsoffererstatningsordningen er subsidicer, og hensynet til statens budsjettering er tungtveiende. Et tredje alternativ er å sette grensen høyere enn 40 G. Settes den for eksempel til $60 \mathrm{G},{ }^{272}$ vil få rammes av den. Heving til $40 \mathrm{G}$ er likevel en fordobling av dagens grense, og flertallet av de etterlatte i 20 G-sakene ville oppnådd full erstatning med denne grensen. Selv om det opereres med en grense på $40 \mathrm{G}$, er det etter min mening uansett hensiktsmessig å anse et drap som et tilfelle overfor hver etterlatt. På den måten ivaretas hensynet til statens utgifter, samtidig som etterlatte får lik mulighet til dekning av tap som andre voldsofre. Dette samsvarer også bedre med alminnelig erstatningsrett.

\subsubsection{Oppsummering}

Slik jeg ser det, har lovgiver foretatt grep som i stor grad sikrer etterlatte rett til erstatning i tråd med ordningens intensjoner. Endringene vil føre til at etterlattes stilling styrkes betraktelig. For det første kan etterlatte tilkjennes erstatning etter voerstl. $\S 4$. For det andre er søsken i særlige tilfelle gitt rett til erstatning på lik linje med andre etterlatte. Videre er kravene til den skadevoldende handlingen endret. Dette kan medføre at flere typer drap vil falle innenfor ordningen og sikre etterlatte erstatning. Det ser også ut til at problemet med oppreisning etter bildrap løser seg.

\footnotetext{
271 Forslag fra mindretallet i forarbeidene, jf. Innst. O. nr. 25 (2007-2008) pkt. 2.

272 Kontoret antar at en $\emptyset$ kning til 60 G, tilsvarer en kostnad på kr 30 millioner, jf. årsrapport for 2006.
} 
På slutten av arbeidet med avhandlingen, ble det fremmet en proposisjon ${ }^{273}$ om å heve beløpsgrensen til 40 G. ${ }^{274}$ Hevingen vil føre til at færre rammes av grensen. Det ble for $\varnothing$ vrig vurdert om et drap skal anses som et tilfelle overfor hver etterlatt, men departementet fant at dette ville være urettferdig overfor for eksempel barn av sterkt skadde voldsofre. ${ }^{275} \mathrm{I}$ disse tilfellene kan det være behov for kompensasjon for foreldrenes inntektstap, slik at barna kan forsørges tilstrekkelig. Det utbetales likevel ikke mer enn beløpsgrensen for voldshandlingen. Jeg antar at departementet ser at skadelidtes død kan medføre $\varnothing$ konomisk gevinst, hvis hver etterlatt kan tilkjennes erstatning opp til $40 \mathrm{G}$. Etter min mening bør likevel ikke dette være til hinder for at etterlatte skal få full erstatning. Lovgiver bør heller se nærmere på pårørendes rettigheter.

273 Fremlagt 14. november 2008.

274 Ot.prp. nr. 12 (2008-2009).

275 Jf. Ot.prp. nr. 12 (2008-2009) s. 3. 


\section{Referanseliste}

\section{Lover}

bal. $\quad$ Lov om ansvar for skade som motorvogner gjer (bilansvarslova) av 3. februar 1961

bl. $\quad$ Lov om barn og foreldre (barnelova) av 8. april $1981 \mathrm{nr} .7$

ftrl. $\quad$ Lov om folketrygd (folketrygdloven) av 28. februar $1997 \mathrm{nr} .19$

fvl. Lov om behandlingsmåten i forvaltningssaker (forvaltningsloven) av 10. februar 1967

mrl. Lov om styrking av menneskerettighetenes stilling i norsk rett (menneskerettsloven) av 21. mai $1999 \mathrm{nr} .30$

rhl. Lov om fri rettshjelp (rettshjelploven) av 13. juni $1980 \mathrm{nr}$. 35

skl. Lov om skadeserstatning (skadeserstatningsloven) av 13. juni 1969 nr. 26

strl. Almindelig borgerlig Straffelov (straffeloven) av 22. mai $1902 \mathrm{nr} .10$

strprl. Lov om rettergangsmåten i straffesaker (straffeprosessloven) av 22. mai $1981 \mathrm{nr} .25$

voerstl. Lov om erstatning fra staten for personskade voldt ved straffbar handling m.m. (voldsoffererstatningsloven) av 20. april 2001 nr. 13

voerstl. Lov om endringer i lov om erstatning fra staten for personskade voldt ved straffbar handling m.m. (voldsoffererstatningsloven) av 21. desember $2007 \mathrm{nr} .125$ 


\section{Forskrifter}

Voldsofferforskriften Forskrift om erstatning fra staten for personskade voldt ved straffbar handling av 11. mars 1976 (opphevet)

Voldsofferforskriften Forskrift om erstatning fra staten for personskade voldt ved straffbar handling av 23. januar $1981 \mathrm{nr} .8983$

\section{Litteratur}

Aall 2003

Aall, Jørgen. Uskyldspresumsjonen etter frifinnende dom. Lov og Rett 2003, s. 249-256.

Andenæs 2004

Andenæs, Johs., Magnus Matningsdal og Georg RieberMohn. Alminnelig strafferett. 5. Utg.

Oslo: Universitetsforlaget, 2004.

Andenæs 2002

Andenæs, Johs. Innføring i rettsstudiet. 6. utg.

Oslo: Cappelen Akademisk forlag, 2002.

Aubert 1982

Aubert, Vilhelm. Rettssosiologi.

Oslo: Universitetsforlaget, 1982.

Bernt og Rasmussen 2003 Bernt, Jan Fridtjof og Ørnulf Rasmussen. Frihagens forvaltningsrett, Bind $I$.

Bergen: Fagbokforlaget, 2003. 
Boe 1996

Brath 2007

Eckhoff og Helgesen 2001

Eckhoff og Smith 2006

Hellevik 2005

Hov 2007

Kjelland 2007a

Kjelland 2007b

Kjelland 2002
Boe, Erik. Innføring i juss: juridisk tenkning og rettskildelare. Oslo: Tano Aschehoug, 1996.

Brath, Henning. Lovkommentar til lov om

Voldsoffererstatning. I: Norsk lovkommentar nettversjon. (Gyldendal rettsdata)

Eckhoff, Torstein og Jan Helgesen. Rettskildelare. 5. utg. Oslo: Universitetsforlaget, 2001.

Eckhoff, Torstein og Eivind Smith. Forvaltningsrett. 8. utg. Oslo: Universitetsforlaget, 2006.

Hellevik, Ottar. Sosiologisk metode. 2. utg. Oslo: Universitetsforlaget, 2005.

Hov, Jo. Rettergang I. Oslo: Papinian, 2007.

Kjelland, Morten. Sarlig sårbarhet $i$

personskadeerstatningsretten: en analyse av generelle og spesielle regler om årsakssammenheng.

Utgave av dr.jurisavhandling.

Kjelland, Morten. Kapittel 3: Årsakssammenheng.

I: Personskadeoppgjør. Sandvika: BI

Forsikringsakademiet, 2007, s. 43-94.

Kjelland, Morten. Hjemmearbeideres erstatningsrettslige vern. Oslo: Gyldendal Akademisk, 2002. 
Lødrup 2005

Lødrup 2008

Martinussen 1991

Mathiesen 2005

Møse 2002

Nygaard 2007

Schønning 1991

Schiøtz, Wergeland og Bratt

Skjerdal 1999
Lødrup, Peter. Larebok i erstatningsrett. 5. utg.

Oslo: Gyldendal Akademisk, 2005.

Lødrup, Peter. Oversikt over erstatningsretten. 6. utg. Oslo: Cappelen Akademisk Forlag, 2008.

Martinussen, Willy. Sosiologisk analyse: en innføring. 3. utg. Oslo: Universitetsforlaget, 1991.

Mathiesen, Thomas. Retten $i$ samfunnet. 5. utg. Oslo: Pax, 2005.

Møse, Erik. Menneskerettigheter.

Oslo: Cappelens Forlag, 2002.

Nygaard, Nils. Skade og ansvar. 6. utg.

Bergen: Universitetsforlaget, 2007.

Schønning, Albert. Erstatning fra staten til voldsofre. 2.utg. Oslo: Universitetsforlaget, 1991.

Schiøtz, Aina, Ebba Wergeland og Unni Bratt.

Debatt: medisinsk sakkyndighet i yrkessykdomssaker moral misforstått som vitenskap.

Tidsskrift for rettsvitenskap, 2008 nr. 01, s. 75-86.

Skjerdal, Nicholai V. Duplikk til Aslak Syse.

Lov og Rett 1999, s. 185. 
Strandbakken 2003

Syse 1999

Syse 1999

Tømmerås 2002
Strandbakken, Asbjørn. Uskyldspresumsjonen "in dubio pro reo”. Bergen: Fagbokforlaget, 2003.

Syse, Aslak. Tap av fors $\phi$ rger- $\phi k o n o m i s k ~ g e v i n s t ?$

Lov og Rett 1999, s. 47-60.

Syse, Aslak. Skal Matteusprinsippet fortsatt styre erstatningsretten? Replikk til Nicholai V. Skjerdal.

Lov og Rett 1999, s. 183-184.

Tømmerås, Ane Sofie. Billighetserstatning og andre offentlige erstatningsordninger.

Oslo: Universitetsforlaget, 2002.

\section{Internasjonale konvensjoner og rapporter}

EMK

SP

Voldsofferkonvensjonen

Voldsofferkonvensjonens

forklarende rapport
Europarådets konvensjon om beskyttelse av menneskerettighetene og de grunnleggende friheter (Den europeiske menneskerettskonvensjon) av 4. november 1950 .

De forente nasjoners internasjonale konvensjon om sivile og politiske rettigheter av 16. desember 1966.

European Convention on the Compensation of Victims of Violent Crimes, CEST No.: 116 av 24. November 1983.

European Convention on the Compensation of Victims of Violent Crimes, CEST No.: 116, Explanatory Report. 


\section{Offentlige dokumenter}

Innst. O. nr. 46 (2000-2001) Innstilling fra justiskomiteen om lov om erstatning fra staten for personskade voldt ved straffbar handling m.m. (voldsoffererstatningsloven).

Innst. O. nr. 25 (2007-2008)

NOU 2000: 33

NOU 2006: 10

Fornærmede i straffeprosessen - nytt perspektiv og nye rettigheter

NOU 2008:4

St.prp. nr. 39 (1975-1976)

Ot.prp. nr. 4 (1972-1973)

Om lov om endringer i erstatningslovgivningen m.m.

Ot.prp. nr. 4 (2000-2001)

Om lov om erstatning for personskade voldt ved straffbar handling m.m (voldsoffererstatningsloven).

Ot.prp. nr. 30 (2006-2007)

Om lov om endringer i bilansvarslova (gjennomføring av femte motorvognforsikringsdirektiv mv.) 
Ot.prp. nr. 10 (2007-2008)

Ot.prp. nr. 12 (2008-2009)
Lov om endringer i lov om erstatning fra staten for personskade voldt ved straffbar handling m.m. (voldsoffererstatningsloven).

Om lov om endringar i lov om erstatning frå staten for personskade valda ved straffbar handling m.m. (valdsoffererstatningslova).

\section{Domsregister}

Rt. (Norsk Retstidende)

$\begin{array}{ll}\text { Rt. } 1913 \text { s. } 619 & \text { Norsk Hovedjernbane } \\ \text { Rt. } 1922 \text { s. } 73 & \text { Sundre } \\ \text { Rt. } 1973 \text { s. } 1268 & \text { Flymanфver } \\ \text { Rt. } 1976 \text { s. } 1302 & \text { Svanevik } \\ \text { Rt. } 1992 \text { s. } 64 & \text { P-pille II } \\ \text { Rt. } 1993 \text { s. } 1524 & \text { Ølberg } \\ \text { Rt. } 1997 \text { s. } 1 & \text { Rossnes } \\ \text { Rt. } 1998 \text { s. } 639 & \text { Bastrup } \\ \text { Rt. } 1998 \text { s. } 1565 & \text { Lie } \\ \text { Rt. } 1999 \text { s. } 293 & \text { Bistandsadvokat } \\ \text { Rt. } 1999 \text { s. } 864 & \text { Ringvold } \\ \text { Rt. } 1999 \text { s. } 887 & \text { Akbari } \\ \text { Rt. } 1999 \text { s. } 1363 & \text { Karmøy } \\ \text { Rt. } 2000 \text { s. } 418 & \text { Thelle } \\ \text { Rt. } 2001 \text { s. } 274 & \text { Knivdrap } \\ \text { Rt. } 2001 \text { s. } 320 & \text { Nilsen } \\ \text { Rt. } 2001 \text { s. } 337 & \text { Ranheim } \\ \text { Rt. } 2002 \text { s. } 481 & \text { Giftdrap }\end{array}$




$\begin{array}{ll}\text { Rt. } 2003 \text { s. } 1459 & \text { Catwalk } \\ \text { Rt. } 2004 \text { s. } 592 & \text { Geriljasoldat } \\ \text { Rt. } 2004 \text { s. } 750 & \text { Rica II } \\ \text { Rt. } 2004 \text { s. } 1324 & \text { Haglegevaer } \\ \text { Rt. } 2005 \text { s. } 104 & \text { Drapsfors } \phi k \\ \text { Rt. } 2005 \text { s. } 289 & \text { Sprengladning } \\ \text { Rt. } 2005 \text { s. } 1322 & \text { Aluminiumsbåt } \\ \text { Rt. } 2006 \text { s. } 61 & \text { Lekestativ } \\ \text { Rt. } 2006 \text { s. } 1217 & \text { Angiografi } \\ \text { Rt. } 2007 \text { s. } 172 & \text { Schizofreni } \\ \text { Rt. } 2007 \text { s. } 1777 & \text { Båtdrap }\end{array}$

\section{Avgjørelser fra Erstatningsnemnda for voldsofre}

ENV 2000/284

ENV 2003/248

ENV 2004/180

ENV 2004/256

ENV 2004/316

ENV 2004/332

ENV 2044/1912

ENV 2004/2113

ENV 2004/2290

ENV 2005/230

ENV 2005/248

ENV 2005/557

ENV 2005/569

ENV 2005/1084a

ENV 2005/2028 
ENV 2005/3976

ENV 2006/712

ENV 2006/1030

ENV 2006/1033

ENV 2006/1159

ENV 2006/2524

ENV 2007/855

ENV 2007/967

ENV 2007/1364

ENV 2007/3647

ENV 2007/4050

ENV 2007/4048

\section{Avgjørelser fra EFTA- domstolen og EF- domstolen}

Case E-8/07

Case C-348/98
Nguyen v. Norge, 20. juni 2008, Luxemburg.

Ferreira v. Comphania de Seguros Mundial Confianca SA, Sml. 2000 s. 1-6711

\section{Avgjørelser fra EMD}

Application no. 31283/04 Orr v. Norway, 15. mai 2008, Strasbourg. 


\section{Elektroniske kilder}

Grunnbeløpet, NAV, http://www.nav.no/page?id=1073744172 [Sitert 01.09.08]

Drapsstatistikk 2007, Kripos, http://www.politi.no/pls/idesk/docs/f1537358626/drapsstatistikk2007.pdf [Sitert 15.09.08]

Statsbudsjettet 2009, Regjeringen,

http://www.regjeringen.no/pages/2113139/PDFS/STP200820090001GULDDDPDFS.pdf [Sitert 07.10.08]

\section{Rapporter og seminar}

Årsrapport 2006

Seminar 6. august 2008
Kontoret for voldsoffererstatning, Vardø. Arsrapport 2006. Ved Remi Strand, direktør ved Kontoret for voldsoffererstatning i Vard $\emptyset$.

\section{Muntlige kilder/kontakter}

Bastiansen Advokatfullmektig Marte Bastiansen, Advokatfirmaet Salomon \& Johansen

Giertsen Professor Hedda Giertsen, Institutt for kriminologi og rettssosiologi

Karlsen Advokat Roy Hedly Karlsen, Advokatene Christian Wiig \& Co AS

Ness Advokat Jan Gunnar Ness, Advokatfirma Ness \& Co

Oretorp Seniorrådgiver Per Oretorp, Landsforeningen for trafikkskadde (LTN)

Sandvold Advokat Carl Gunnar Sandvold, Erstatningsnemnda for voldsofre

Strand Remi Strand, direktør ved Kontoret for voldsoffererstatning

Sørum Advokat Tom Sørum, Advokatfirma Ness \& Co 
$7 \quad$ Lister over tabeller og figurer $\mathrm{m} \mathrm{v}$

Figur 1

Tabell 1

Tabell 2

Tabell 3 s. 20.

s. 42 .

s. 55.

s. 59. 


\title{
8 Vedlegg 1: Anbefalelsesbrev
}

\section{Morten Kjelland}

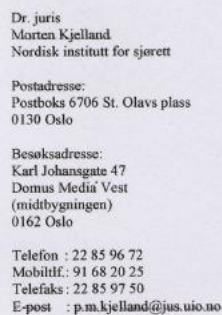
Line Svinndal - spesialavhandling om etterlattes stilling etter
voldsoffererstatningsloven

\begin{abstract}
Prosjektet «Etterlattes stilling etter voldsoffererstatningsloven» tar sikte på å gi en rettsdogmatisk og dels empirisk analyse av reglene om etterlattes erstatningsvern. Avhandlingen vil gi en oppdatert analyse av de formelle reglene om etterlatteerstatning. Fremstillingen vil også belyse faktiske sider ved erstatningsinstituttet. Målsettingen er å kartlegge et utsnitt av den reelle retten. Det er i denne forbindelsen Svinndal skal foreta empiriske undersøkelser. For å kunne realisere prosjektet er det søkt om fritak for taushetsplikten.
\end{abstract}

Det har ikke vært foretatt tilsvarende kombinerte og komparative analyser av reglene om etterlatteerstatning basert på den norske voldsoffererstatningsordningen. Prosjektet kan gi et interessant og ønskelig bidrag til eksisterende fremstillinger.

På denne bakgrunn anbefaler jeg at Line Svinndal gis mulighet for tilgang til data og respondenter, slik at hun kan foreta kildeinnsamlingen knyttet til sine undersøkelser.

Dersom det er spørsmål, så ta kontakt. Jeg treffes i denne perioden enklest på mobiltelefon 91682025 .

Morten Kjelland

Dr. juris/veileder

28. juni 2008 


\section{Vedlegg 2: Vedtak om innsyn}

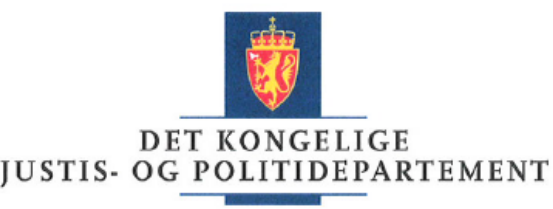

Kontoret for voldsoffererstatning

Remi Strand

$\mathrm{Pb} 253$

9951 VARD

Deres ref.

Vầr ref

Dato

200805036- /CHA $\quad 18.08 .2008$

Søknad om innsyn i dokumenter til bruk i forskning ifm. masteroppgave om etterlattes stilling etter voldsoffererstatningsloven

Vi viser til din e-post av 4. august 2008 og til søknad fra Line Svinndal av 28. juli 2008 om innsyn i dokumenter til bruk i forskning. Opplysningene skal brukes i forbindelse med masteroppgave ved Det juridiske fakultet ved Universitetet i Oslo. Veileder for oppgaven er dr. juris Morten Kjelland ved Universitetet i Oslo.

Tema for oppgaven er etterlattes stilling etter voldsoffererstatningsloven. Prosjektet tar sikte på å gi en rettsdogmatisk og dels empirisk analyse av reglene om etterlattes erstatningsvern. Avhandlingen vil gi en oppdatert analyse av de formelle reglene om etterlatteerstatning. Fremstillingen vil også belyse faktiske sider ved erstatningsinstituttet. Målsettingen er å kartlegge et utsnitt av den reelle retten.

Departementet legger vekt på at oppgaven vil kunne bidra til å belyse hvordan etterlattes stilling faktisk blir ivaretatt etter voldsoffererstatningsloven.

På denne bakgrunn finner Justisdepartementet det klart at søknaden bør innvilges, og saken behøver derfor ikke forelegges for Rådet for taushetsplikt og forskning jf. forskrift av $15.12 .2006 \mathrm{nr}$. 1456 (forvaltningsforskriften) $\S 9$, annet ledd.

I medhold av forvaltningsloven $\S 13 \mathrm{~d}$ bestemmer Justisdepartementet at Kontoret for voldsoffererstatning kan gi Line Svinndal innsyn i saker som gjelder vedtak om voldsoffererstatning til etterlatte og andre vedtak om voldsoffererstatning i den grad det er nødvendig for oppgaven.

Postadresse

Kontoradresse Telefon-sentralbord

22249090

Org. nr:: 972417831

Telefaks

Saksbehandler

Carl Håkon Andersen

22245521 
Departementet forutsetter at de personene de aktuelle dokumentene omfatter ikke kan identifiseres i den endelige rapporten, og at opplysningene behandles i tråd med taushetspliktsbestemmelsene i forvaltningsloven. Vi minner i denne forbindelse om bestemmelsen i forvaltningsloven $\S 13 \mathrm{e}$, som lyder:

§13e. (forskeres taushetsplikt).

Enhver som utfører tjeneste eller arbeid i forbindelse med en forskingsoppgave som et forvaltningsorgan har støttet, godkjent eller gitt opplysninger undergitt taushetsplikt til, plikter å hindre at andre făr adgang eller kjennskap til:

1. opplysninger undergitt taushetsplikt som forskeren fär fra et forvaltningsorgan,

2. opplysninger som i forbindelse med forskningsarbeidet er mottatt fra private under taushetsløfte, og

3. opplysninger som gjelder personer som står $i$ et avhengighetsforhold til den instans (skole, sykehus, anstalt, bedrift, offentlig myndighet m.m.) som har formidlet deres kontakt med forskeren.

Opplysningene kan bare brukes slik det er nødvendig for forskingsarbeidet og $i$ samsvar med de vilkår som måtte vare fastsatt etter $\$ 13$ d annet ledd. Skal resultater av

forskingsarbeidet publiseres eller brukes pà annen måte, gjelder $\S 13 \mathrm{a} \mathrm{nr} .1$ og 2 tilsvarende.

Brudd på taushetsplikten eller på vilkår etter $\$ 13$ d annet ledd, straffes etter straffelovens $\$ 121$. Departementet eller vedkommende forvaltningsorgan skal gjøre forskeren og hans medarbeidere kjent med taushetsplikten og straffebestemmelsen, jfr. også $\$ 13 \mathrm{c}$ forste ledd.

Vi forutsetter videre at Svinndal ikke tar direkte kontakt med de personene opplysningene angår, og at utlevert materiale makuleres etter bearbeiding. Departementet ber om at Kontoret for voldsoffererstatning gjør Svinndal kjent med taushetsplikten og de forutsetninger som følger av dette brevet.

Nærmere avklaring om den praktiske gjennomføringen av innsynet må skje i samarbeid mellom Svinndal og Kontoret for voldsoffererstatning.

Med hilsen

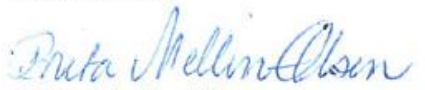

Brita Mellin-Olsen

underdirektør

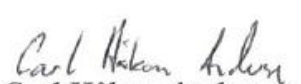

Carl Håkon Andersen

førstekonsulent 
Kopi:

Rådet for taushetsplikt og forskning

Morten Kjelland, Nordisk institutt for sjørett, postboks 6706 St. Olavs plass, 0130 Oslo 